\title{
Long-term and large-scale variability in productivity of the tellinid bivalve Macoma balthica on Wadden Sea tidal flats
}

\author{
R. Dekker*, J. J. Beukema \\ Royal Netherlands Institute for Sea Research, PO Box 59, 1790AB Den Burg, Texel, The Netherlands
}

\begin{abstract}
A series of 27 successive annual estimates of production of soft parts of the bivalve Macoma balthica (L.) populating the tidal flats of Balgzand (western Wadden Sea, The Netherlands) was obtained using multi-station (15 sites) and long-term (27 yr: 1978 to 2004, inclusive) monitoring data on numerical densities and ash-free dry mass (AFDM). Annual production values were estimated from seasonal growth increments, which were positive in spring and early summer and (in adults) negative in the remainder of the year, when up to $70 \%$ of individual weight gain of the preceding growing season was lost. Annual estimates based on twice-annual sampling were checked and refined on the basis of a detailed 2 yr study. Weight loss proportions increased with age of animals and with water temperature in winter. Net annual somatic production of the entire population varied from 1 to 9 (27 yr mean: $2.9 \pm 0.3$ ) g AFDM m${ }^{-2} \mathrm{yr}^{-1}$. Lifetime production per individual averaged $0.007 \mathrm{~g}$ AFDM for recruits of $\sim 3 \mathrm{mo}$ old and $0.032 \mathrm{~g}$ AFDM for 10 mo olds. Numerical densities of $\sim 10$ mo old recruits predicted, within narrow limits, subsequent cohort production by way of a positive linear relationship. However, production of 3 mo old recruits was on average higher at low than at high densities, owing to better juvenile survival at low densities. Local (between-station) variation in mean annual production was primarily related to local variation in recruitment. However, production per recruit was significantly higher at low than at high intertidal levels, in accordance with higher growth and lower mortality rates at lower levels. Strong temporal and local variation was also found in annual production/biomass $(P / \bar{B})$ ratio values, which reflected the variable age composition of the population: $P / \bar{B}$ ratio values were augmented whenever mean age was low. Consistently higher mean $P / \bar{B}$ ratio values ( 0.6 vs. $\sim 0.4 \mathrm{yr}^{-1}$ ) were found at high near-coast compared with low off-shore tidal flats, in accordance with higher mortality rates on high flats. Environmental factors affecting variation in annual production included between-year variability in recruitment (which was related to winter temperature and shrimp predation pressure) and growth (which was related to diatom abundance).
\end{abstract}

KEY WORDS: Long-term data $\cdot$ Seasonal growth $\cdot$ Annual recruitment - Secondary production · Tidal flats

Resale or republication not permitted without written consent of the publisher

\section{INTRODUCTION}

Quantitative studies of energy transfer along food chains require reliable estimates of annual production at both the primary and secondary (consumer) level. In contrast to the straightforward assessment of total algal stock primary production (by measurements of fluxes of carbon dioxide or oxygen), the only method to estimate secondary production in an ecosystem is a laborious one: addition of (usually numerous) separate estimates at the level of individual species. An associated benefit of this latter approach is that the role of an individual species in ecosystem functioning can be characterized in a more meaningful way than by its contribution to either total biomass or total numbers. Owing to the notorious variability in abundance 
(both in time and space) of bivalves (and many other groups), representative estimates of their production rates can be obtained only from consistent long-term data gathered simultaneously at many stations. This is laborious, and it is therefore understandable (but unfortunate) that such elaborate studies in the marine environment are few.

The tellinid bivalve Macoma balthica (L.) is an important member of the benthic community of coastal seas and estuaries, including the tidal flats of the Wadden Sea (Desprez et al. 1991). As with other bivalves in coastal marine environments, populations of this species show strong temporal and spatial variability in their annual recruitment (Beukema et al. 2001a, Strasser et al. 2003), total numbers (Desprez et al. 1991, Beukema 1993), biomass (Beukema et al. 1993) and production (Wolff \& De Wolf 1977, Elliott \& McLusky 1985). Annual recruitment in particular appears to govern temporal variability in $M$. balthica production (Van der Meer et al. 2001a). Notwithstanding its marked variability, this species was found in every year of our study (1978 to 2004) at all 15 sampling stations (scattered over a $50 \mathrm{~km}^{2}$ area), making it a preeminently suitable species from which to: (1) obtain a continuous and detailed series of production estimates; (2) study the temporal and spatial variability of these estimates; and (3) detect the underlying causes of variability.

Earlier studies based on the same data set were restricted to annual shell production (Macoma balthica: Beukema 1980; Cerastoderma edule: Beukema 1982), while Van der Meer et al. $(2001 \mathrm{a}, \mathrm{b})$ studied cohort production of soft parts of $M$. balthica by estimating annual rates of elimination (i.e. by summation of removal of entire animals). We preferred to study production by the weight-increment summation method (for an explanation of methods see Van der Meer et al. 2005), in order to enable (in a later study) direct comparisons between estimates of primary and secondary production.

Shell production is easier to reliably assess than is production of soft parts: weights of shells do not change outside the growing season, whereas the soft parts of bivalves generally loose a substantial part of their weight annually within a given period of several months, making net annual production substantially lower than growing-season production. As explained by Beukema \& Dekker (2006), obtaining unbiased estimates of production rates in species with an annual cycle of gain and loss of soft-part weight makes special demands of the data set, including sampling at the right time of the year, i.e. preferably timed to coincide with the 2 annual reversals of weight change. Possible bias deriving from twice-annual sampling was evaluated using results of a preceding detailed study
(Beukema \& De Buin 1977) of seasonal growth rates that incorporated frequent sampling of the Macoma balthica population at 1 station over 2 yr (1968 and 1969). This evaluation prompted minor corrections of raw production estimates in slightly more than half of the years included in the present study.

In this study we pay special attention to the variability and workability of annual $P / \bar{B}$ ratio values. As explained by Van der Meer et al. (2005), rough estimates of production $(P)$ are frequently deduced from (more easily obtainable) values of mean annual biomass $(\bar{B})$. Our long data series of estimates of both $P$ and $\bar{B}$ facilitate an answer to the question of whether variability of annual $P / \bar{B}$ values would be sufficiently low to enable reliable estimates of $P$ from known values of $B$ in populations of Macoma balthica.

The aims of the present study were to: (1) assess reliable unbiased long-term estimates of annual Macoma balthica production and $P / \bar{B}$ ratios from a vast area that may be considered representative of the tidal flats of the entire Wadden Sea; (2) gain insight into the temporal and spatial variability of $M$. balthica productivity and its underlying causes, such as temporal and spatial variability in recruitment; and (3) explore possible sources of error in production estimates and to recommend proper methods.

\section{MATERIALS AND METHODS}

Data collection. Since the 1970 s, the macrozoobenthos community has been monitored at 15 fixed sampling sites (12 transects of $1 \mathrm{~km}$ each and 3 quadrats of $30 \times 30 \mathrm{~m}$, Fig. 1) on a $50 \mathrm{~km}^{2}$ tidal flat area called 'Balgzand' in the westernmost part of the Dutch Wadden Sea $\left(\sim 53^{\circ} \mathrm{N}\right.$ and $\left.5^{\circ} \mathrm{E}\right)$. The monitoring program comprises twice-annual (late winter: mostly March, and late summer: mostly August) estimates of numbers and biomass of all macrobenthic (those retained on $1 \mathrm{~mm}$ sieves) animal species. Details of sampling sites and methods can be found in earlier publications (e.g. Beukema \& Cadée 1997). Sampling sites are scattered (almost) randomly over the tidal flats of Balgzand and cover the entire intertidal depth range (see Fig. 1b of Beukema \& Cadée 1997), which runs on average from about +6 to $-8 \mathrm{dm}$ relative to mean-tide level (MTL). The level of near-shore sites is generally above MTL, and these sites are immersed for less than half of the time. Levels of sites further offshore are increasingly lower and the 2 farthest sites remain permanently immersed for more than half of the low tides. The sampling sites cover a wide range of sediment composition. Mud (material $<60 \mu \mathrm{m}$ ) content of the top $5 \mathrm{~cm}$ of sediment ranges from $>10 \%$ near the SW coast to $<1 \%$ in the far offshore parts of Balgzand. 

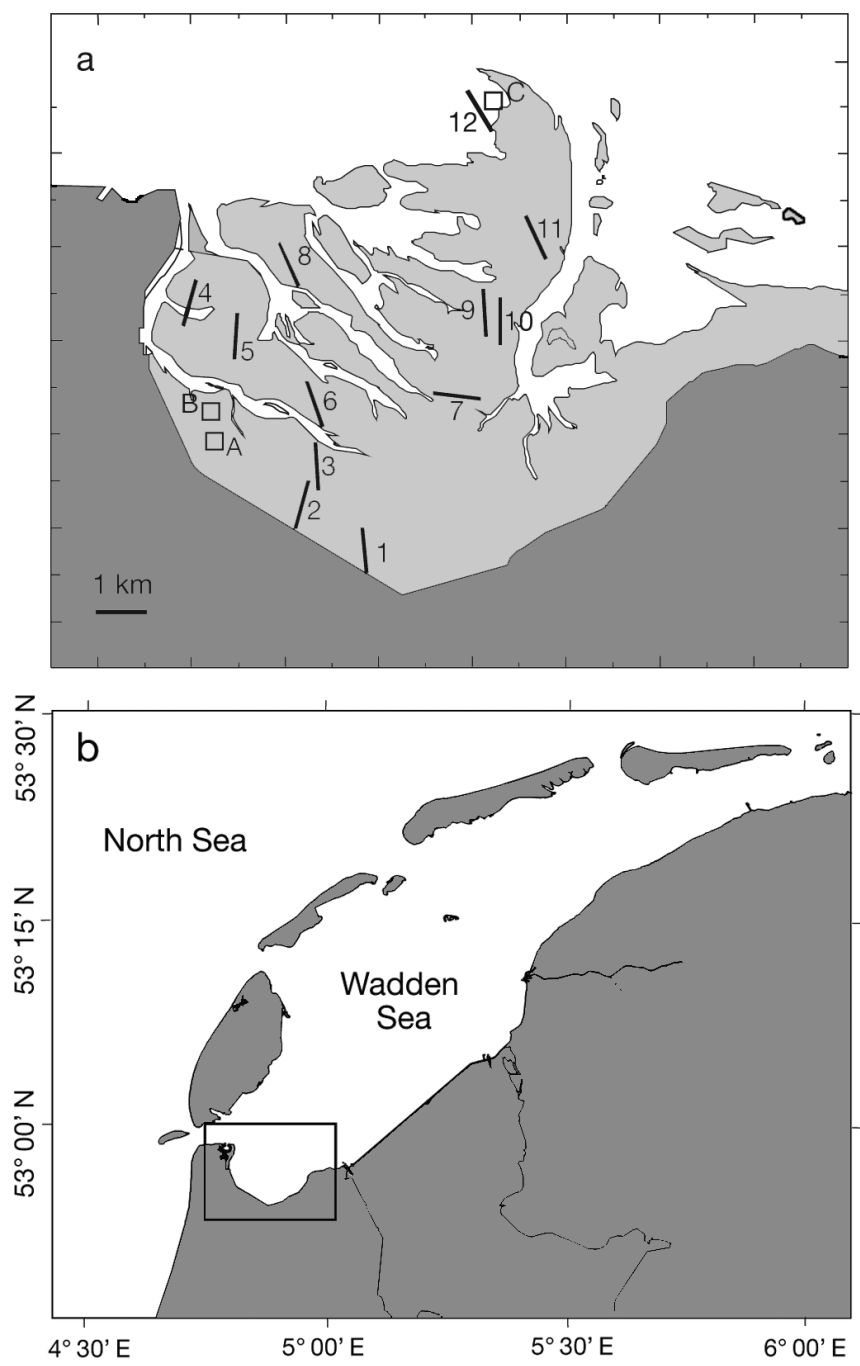

Fig. 1. (a) Location of 15 sampling stations on Balgzand: 12 transects of $1 \mathrm{~km}$ (1 to 12) and 3 squares of $900 \mathrm{~m}^{2}$ (A to C).

(b) Location of Balgzand in the western Wadden Sea

Along each of the 12 transects, 50 cores were taken at equal intervals $(20 \mathrm{~m})$, covering a total of $0.45 \mathrm{~m}^{2}$ (summer) or $0.9 \mathrm{~m}^{2}$ (winter) per transect. The 18 to 32 samples taken per square covered 1 to $1.6 \mathrm{~m}^{2}$. Larger samples were taken along the transects in winter than in summer (1.8 vs. $0.9 \mathrm{dm}^{2}$ ), because numerical densities were generally lower in winter than in summer (and we needed a certain minimal number of individuals to estimate their mean weight with sufficient precision). We did not change our methods during the decades-long monitoring program. Therefore, the 27 yr data series (1978 to 2004) is homogeneous. All Macoma balthica were sorted from the sieved samples, measured and opened by short immersion in boiling water to remove the soft parts. These were dried ( 2 or $3 \mathrm{~d}$ at $60^{\circ} \mathrm{C}$ in a ventilated stove), weighed (individu- ally or per $1 \mathrm{~mm}$ shell-length class), and incinerated. Ash-free dry mass (AFDM) is dry weight minus ash weight. All data on abundance $N$ are expressed in ind. $\mathrm{m}^{-2}$, on biomass $B$ in $\mathrm{g}$ AFDM $\mathrm{m}^{-2}$ and on production $P$ in $\mathrm{g}$ AFDM m ${ }^{-2} \mathrm{yr}^{-1}$. The mean annual value of biomass for a given year was an average of biomass values estimated in March and August of that year.

Shells were assigned to age classes by external examination of the number of year marks on the shell, following Lammens (1967). We are confident that the marks read were truly annual, because strong cohorts could be easily traced as peaks in the length-frequency distributions for several years after their appearance.

For some estimates of mean production, we combined data from Stns C and 12 (see Fig. 1) because these 2 nearby sites generally showed low numerical densities (and we wanted to avoid as many values of 0 as possible). For cohort-based long-term averages we used data series of 25 or 26 items instead of 27 , because lifetime production of cohorts recruited as late as 2001 or 2002 was not yet completed at the time of writing.

Values of (somatic) production were estimated following the weight-increment summation method described by Van der Meer et al. (2005). We made separate calculations for half-year periods and for individual sampling sites. As annual estimates (March to March) we used the sum of 2 successive half-year estimates, i.e. March to August (growing season with mostly positive values) and August to March (weightloss season with mostly negative values). For each of the 15 stations and 54 half-year periods ( $t$ to $t+1$ ), we defined $P$ as the product of mean numerical density $\left(0.5 N_{t}+0.5 N_{t+1}\right)$ and weight change $\left(w_{t+1}-w_{t}\right)$, where $N_{t}$ and $N_{t+1}$ are the numerical densities (ind. $\mathrm{m}^{-2}$ ) at the start and end of the production period, respectively, and $w_{t+1}$ and $w_{t}$ are the mean soft-part AFDM per individual at these times. Estimates of $N$ and $W$ were obtained separately per year class (cohort: all individuals recruited in the same year).

We did not succeed in estimating production during the first growing season. The first estimates of $N$ and $w$ available for each cohort were of spat-sized animals in August, 23 mo after their settlement (see Beukema \& Dekker 2005). At that time, most growth in the first growing season was already completed. The total biomass of spat-sized animals found in August would represent a minimal estimate of spat production before August, but the true production (including their biomass at settlement and production by spat that had died between settlement in May-June and sampling in August) must have been higher, maybe twice the biomass observed in August. We arbitrarily adopted a value of $2 \times$ spat biomass in August as a rough estimate of production of spat-sized animals in their first growing season. 
Data correction. The long-term study was preceded by a detailed study of seasonal growth rates that involved frequent sampling of the Macoma balthica population at Stn B (Fig. 1) during 1968 and 1969, when approximately 16 samples of $0.1 \mathrm{~m}^{2}$ and 16 samples of $0.01 \mathrm{~m}^{2}$ were taken every month. On each sampling occasion and for each cohort, mean numerical density, mean length, mean dry shell weight and mean AFDM were assessed. Some of these results are given by Beukema et al. (1985). To calculate monthly production values (using the growth-increment method described above), we used estimates of numerical density on the 15th of each month and mean weight on the 1 st of each month. These values were obtained by interpolation of the actual data, involving some smoothing by eye of successive density assessments. Use of this procedure allowed us to avoid erratic values.

Like several other bivalves in the Wadden Sea (Zwarts 1991, Honkoop \& Beukema 1997), Macoma balthica exhibits a consistent annual pattern of individual weight change, with annual maximum values recorded at the end of the growing season in summer and minimal values recorded at the end of a weightloss season that extends over most of autumn and winter (Beukema \& De Bruin 1977, Beukema et al. 1985). In such species, unbiased estimates of annual net production can be best obtained by sampling populations at annual peaks and troughs of individual weight, as described by Beukema \& Dekker (2006). For M. balthica this would involve at least twice-annual sampling: in March and around July 1. Fortunately, at the beginning of the monitoring program, we had chosen the February/March period as the main annual sampling period for Balgzand zoobenthos. Usually, rates of weight change in February and particularly March were so small that slight differences in sampling time at this time of the year would negligibly affect the resulting estimate. In only 1 exceptional year (1991) out of the $>27 \mathrm{yr}$ of monitoring did we observe seasonal growth to have begun already in March, as shown in Fig. 3 of Beukema \& Cadée (1996). To properly allot March 1991 production to the estimate of the spring growing season of 1991, rather than to that of the previous year (March 1990 to March 1991), we recalculated the values that were derived from samples taken in mid- and late-March 1991 by reducing biomass values by a date-dependent factor of between $\sim 10$ to $\sim 50 \%$ (according to the condition factors shown in Fig. 3 of Beukema \& Cadée 1996). No further corrections were applied to our March sampling data.

The second annual sampling period was in August. From frequent observations at some stations, we know that in almost half of the years the peaks in individual mean weights occurred within this month, but in slightly more than half of the years the sampling time was too late to capture maximal individual weights (Beukema \& De Bruin 1977, Beukema et al. 1985). Therefore, we judged corrections of our raw seasonal and annual production estimates to be optimal in 17 out of the $27 \mathrm{yr}$ of observation. On the basis of the data available from detailed sampling at Stn B in 1968 and 1969 (including frequent sampling in June, July and August), we calculated correction factors to facilitate conversion of our raw production figures (based on standard August sampling) to unbiased production estimates based on estimated maximal individual weights of the season. In 1968, substantial seasonal weight losses only began in late summer and the bias caused by sampling as late as mid-August was negligible: correction factors amounted to an addition of only $4 \%( \pm 2,1 \mathrm{SE}, \mathrm{n}=3)$ to estimates of growing-season production and of $2 \%( \pm 1)$ to estimates of net annual production. In contrast, in the much warmer summer of 1969, losses were observed as early as late June onwards. In that year, correction factors amounted to no less than $39 \%( \pm 5)$ and $26 \%( \pm 9)$ for seasonal and annual production, respectively. As rates of summer weight loss are known to depend on summer water temperatures (see Fig. 5 of Beukema et al. 1985), we calculated correction factors for each year on the basis of mean July water temperature $(T)$. For years when $T$ $<17^{\circ} \mathrm{C}$ (e.g. 1968), we judged that no correction was necessary. We let the correction linearly increase to maximal values of $40 \%$ (seasonal) and $26 \%$ (annual) at a mean July temperature of $20^{\circ} \mathrm{C}$ (higher mean July temperatures were not observed in the area). Mean July water temperatures were made available by H. M. Van Aken (cf. Van Aken 2003). The applied additions to our raw production estimates (based on August and March sampling) thus amounted to $13.3 \times(T-17) \%$ for seasonal and $8.7 \times(T-17) \%$ for net annual production. During the 1978 to 2004 observation period, the applied corrections to net annual production figures varied from 0 to $25 \%$ with a $27 \mathrm{yr}$ average of $8 \%$. We judged underestimates of this magnitude to be sufficiently serious to apply the above correction.

Detailed monthly production estimates calculated for the population at Stn B in 1968 and 1969 enabled us to check whether twice-annual sampling (taking only the raw results of March and August sampling corrected for summer water temperature, just as we did for the long-term data series) would yield estimates of annual production that were equal to the 12 mo sums of production of the 3 cohorts (excluding spat, and grouping old animals) and 2 yr. The 6 comparisons revealed differences that were invariably $<10 \%$ of the sums of the 12 mo estimates. The mean difference between the 2 types of estimates amounted to a negligible $2 \pm 3 \%$. 


\section{RESULTS}

\section{Seasonal pattern of production}

At the Balgzand Stn B, where production was studied in detail, changes in weights of soft parts of Macoma balthica were positive in spring and early summer in all age classes, whereas weight losses predominated in other seasons in adults (Fig. 2). Only spat-sized animals showed positive weight changes between August and March in all 27 yr of the longterm data series (barely visible at the scale of Fig. 2). Maximum weights of soft parts were mostly observed in late June or July, minimal weights in late February or March (detailed data can be found in Fig. 1 of Beukema \& De Bruin 1977 and Fig. 2 of Beukema et al. 1985). Weight losses between summer and late winter were substantial and increased with age: they were not observed after the first growing season, were relatively small (amounting to $\sim 40 \%$ of preceding weight gain) after the second growing season and were substantial after the third $(\sim 70 \%)$ and subsequent $(>80 \%)$ growing seasons.

As a result of these growth/loss patterns, somatic production was invariably positive only in April, May and June, whereas it was generally negative in between August and February (with the exception of

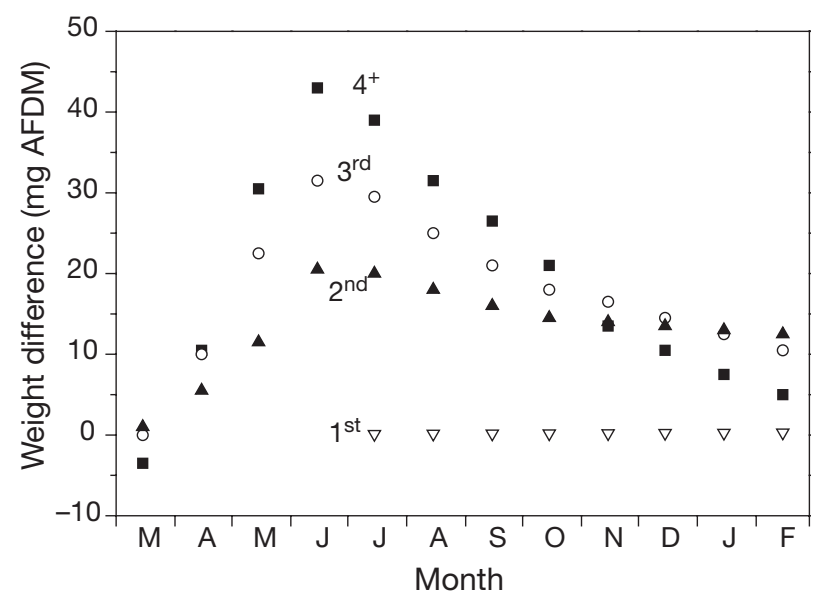

Fig. 2. Macoma balthica. Monthly changes in mean individual weight of soft parts (mg AFDM) over time, expressed either as real weight (spat-sized animals, $\nabla: 1$ st growing season) or as difference between the mid-month weight of each month and earlier weight at preceding March 1 for each of 3 age groups: $\sim 1$ yr olds ( $\boldsymbol{\Lambda}$ : 2nd growing season), $\sim 2$ yr olds (O: 3rd growing season), and older animals ( $\square: 4$ th and subsequent growing seasons). Values are mean of 2 yr (1968 and 1969) from 1 station. Actual mean weights around the start of the growing season (March 1) were $~ 1, ~ 15$ and $~ 40 \mathrm{mg}$ at the start of the 2nd, 3rd, and 4th and subsequent seasons, respectively. Thus, to read actual mean mid-month weights of post-spat age groups, these amounts should be added to the values shown spat-sized animals) (Fig. 3). Note that Fig. 3 deals with somatic production only; inclusion of (unknown) contributions of spawned gamete material would have raised the positive production of early-spring months. In March and July, both positive and negative values were observed (probably depending on prevailing temperatures, see Beukema et al. 1985). Negative production in the (late-)summer to late-winter periods resulted in net annual production figures that were only about half of the production values of the preceding growing season (spring and early summer).

Mean production estimates for 25 cohorts (1977 to 2001, inclusive) determined separately for the successive half-year periods of their life reflected the pattern demonstrated in Fig. 3, i.e. positive values during the growing seasons and negative (but in absolute terms, lesser) values for the subsequent weight-loss seasons (Fig. 4a). The earliest growing seasons of a cohort were always the most productive, with estimates gradually declining with age to negligible values at an age of $\sim 10 \mathrm{yr}$ when numerical densities of that cohort had declined to near-zero values. Outside the growing season, production was invariably positive only in the first year of life (first grey column in Fig. 4a), i.e. mean individual weights of spat-sized animals generally increased between August and March. In subsequent years, the then adult-sized Macoma balthica usually lost weight after the spring-summer season (Fig. 2). In the second year of life, August-to-February contributions to annual net production were more often negative than positive (on 21 cf. 6 occasions; $p<0.01$,

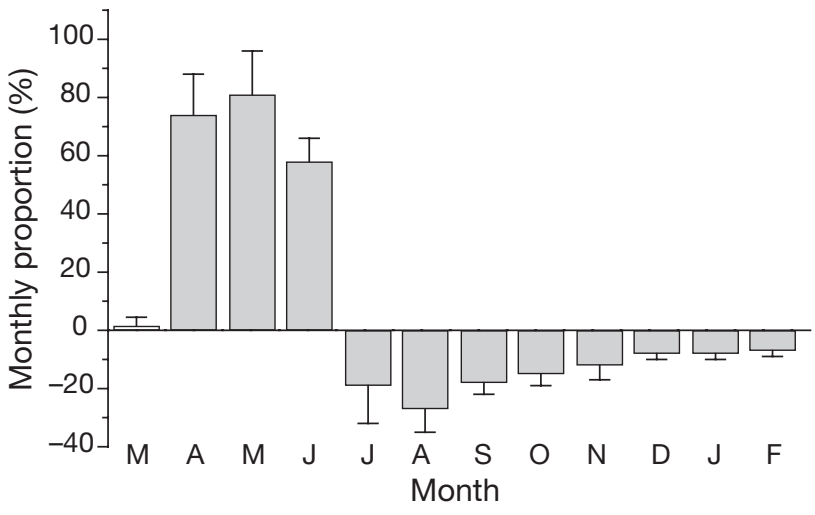

Fig. 3. Macoma balthica. Mean contribution to net annual somatic production at 1 station over time, expressed as mean proportion (\% with $1 \mathrm{SE}, \mathrm{n}=6$ ) of total net annual (March to March) somatic production. Values are means of 6 data sets: production in 1968 of cohorts recruited in 1967, 1966 and $1965^{+}$(1965 and earlier cohorts) and production in 1969 of cohorts recruited in 1968, 1967 and $1966^{+}$(19656 and earlier cohorts). Values were expressed as \% in order to reduce SE, as absolute production values were highly variable among data sets, particularly owing to differences in cohort abundance 

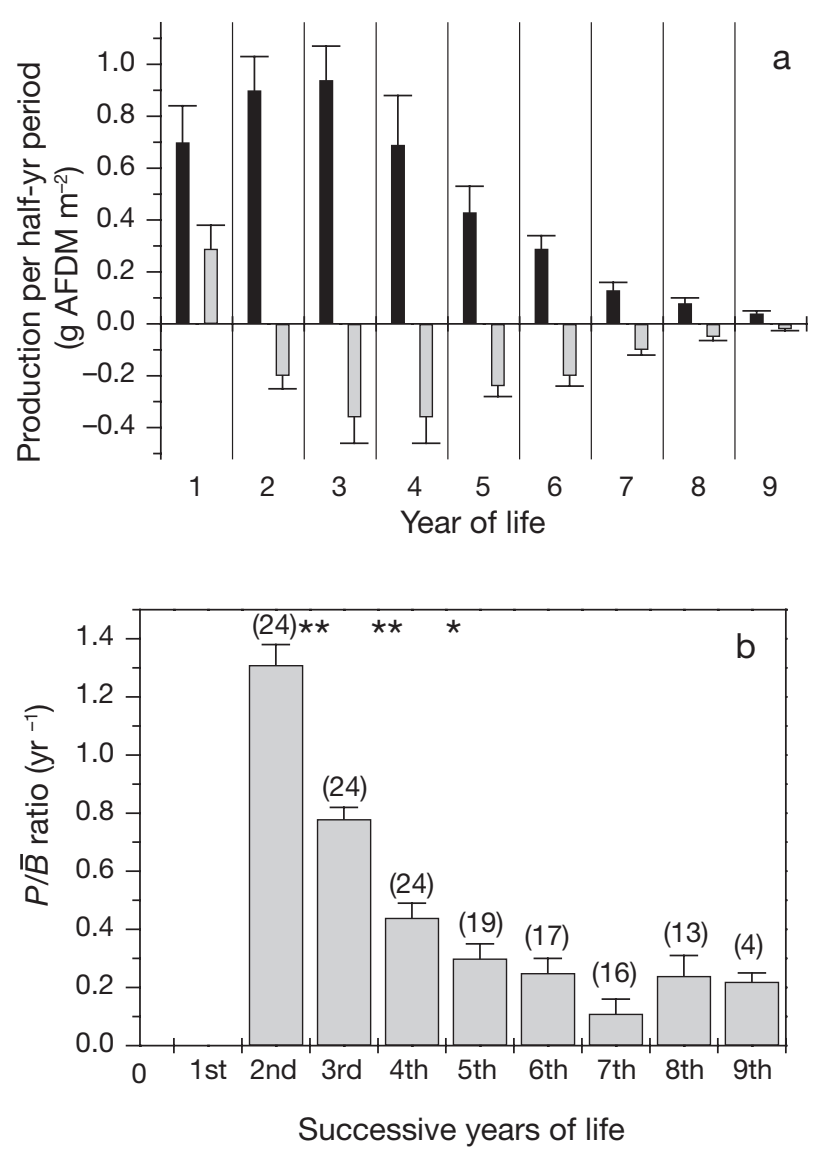

Fig. 4. Macoma balthica. Relationship between age ( $\mathrm{yr}_{\text {; }}$ the 2nd year starts at an age of $10 \mathrm{mo}$, the $3 \mathrm{rd}$ at $22 \mathrm{mo}$, etc.) and: (a) mean half-year production ( $\mathrm{g} A F D M m^{-2}, 1 \mathrm{SE}, \mathrm{n}=25$ ) of 25 cohorts recruited between 1977 and 2001 (mean of all sampling stations). Black columns: production completed within the growing season (March to August, but corrected if actual weight gain ended earlier than mid-August in warm summers); grey columns: remaining part of year. Production during first growing season not actually measured but arbitrarily set at $2 \times$ August spat biomass; (b) mean value of $P / \bar{B}$ ratio (1 SE) of same cohorts. Above bars: no. of observations; initially $n=24$ but declined for older age groups because cohorts were included only as long as mean annual $B$ was $>0.1 \mathrm{~g}$ AFDM m ${ }^{-2} .{ }^{*} \mathrm{p}<0.05 ;{ }^{* *} \mathrm{p}<0.01$ (Wilcoxon test)

ranked-sign test) and were on average relatively small ( $20 \%$ of the preceding growing-season production). In subsequent years of life, only losses were observed over the summer to late-winter period: they amounted to an average of $\sim 40 \%$ in the third year and increased to $>50 \%$ (up to $\sim 70 \%$ ) in later years.

Seasonal weight losses of soft parts of Macoma balthica (and other bivalve species in the Wadden Sea) are related to winter temperatures: the colder the winter, the lower the proportion of weight lost (correlative field study: Zwarts 1991; experimental evidence: Honkoop \& Beukema 1997). As expected, this relation- ship was also found to be true for the proportion of seasonal production lost in the subsequent non-growing season (Fig. 5). In half-year periods characterized by mild winters, relative production losses were roughly double ( 60 vs. $\sim 30 \%$ ) the losses observed in cold winters.

In the last 6 yr of the monitoring period (not included in data shown in Fig. 5), lower losses were observed $\left(\sim 30 \%\right.$, cf. $\sim 50 \%$ at temperatures around $\left.5^{\circ} \mathrm{C}\right)$. These low values can be explained by the unusual age distribution of the population in these years: owing to exceptionally high mortality rates of adult Macoma balthica in recent years, the population consisted almost exclusively of juvenile animals after 1997 (see Fig. 7a) and, as shown above, such young animals lose less weight than older specimens.

\section{Long-term changes in production}

In the 1978 to 2004 period, annual 15-station means of growing-season production of Macoma balthica varied strongly from $\sim 1$ to $\sim 8 \mathrm{~g}$ AFDM m${ }^{-2} \mathrm{yr}^{-1}(\mathrm{O}$ in Fig. $6 \mathrm{~b})$ with a $27 \mathrm{yr}$ mean $( \pm \mathrm{SE})$ of $3.85 \pm 0.43 \mathrm{~g}$ AFDM $\mathrm{m}^{-2} \mathrm{yr}^{-1}$. Seasonal losses of these bivalves amounted to an average of $\sim 1 \mathrm{~g} \mathrm{AFDM} \mathrm{m} \mathrm{m}^{-2} \mathrm{yr}^{-1}$. This figure is the net result of losses of $1.5 \mathrm{~g}$ in adults and gains of $0.5 \mathrm{~g}$ in spat. The resulting annual net production values likewise varied strongly from $\sim 1$ to $\sim 9 \mathrm{~g}$ AFDM m ${ }^{-2} \mathrm{yr}^{-1}$

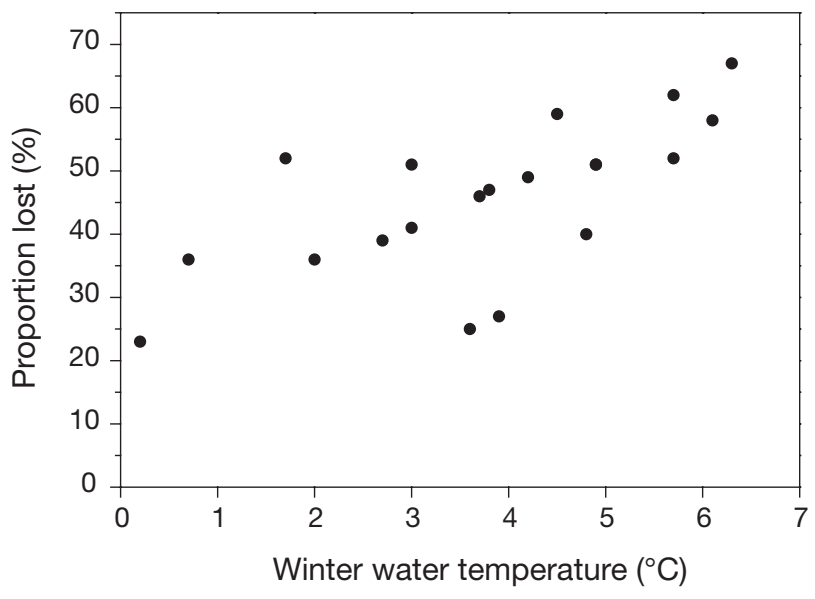

Fig. 5. Macoma balthica. Relationship between mean winter (Dec, Jan, Feb) water temperature $\left(T,{ }^{\circ} \mathrm{C}\right)$ and proportion $(p$, $\%)$ of positive growing-season (spring-summer) production that had to be subtracted from this estimate as negative production in the subsequent part of the year (until March) to obtain an estimate of net annual production for that year; $p=28+4.8 T(\mathrm{n}=20, \mathrm{r}=+0.67, \mathrm{p}<0.01)$. One point for each of $20 \mathrm{yr}$ (1978 to 1997, except for 2 yr which shared the same result). Spat-sized animals excluded; years after 1997 excluded because of altered age distribution (see 'Seasonal pattern of production') 
( in Fig. 6b), with a 27 yr mean of $2.89 \pm 0.33 \mathrm{~g}$ AFDM $\mathrm{m}^{-2} \mathrm{yr}^{-1}$. The long-term growing-season estimate of $3.85 \mathrm{~g}$ thus substantially overestimated net annual production, as shown in more detail in Fig. 4a. In only 4 of the 27 yr did net production exceed growing-season production; these exceptional years were characterized by high proportions of spat-sized individuals, and included the year of recruitment of the strong 1991 cohort and some of the years after 1997 (see Fig. 7a).

A long-term mean of net production was also calculated from the 26 estimates of cohort production (shown in Fig. 6a) and resulted in a (necessarily similar) mean of $2.9 \pm 0.5 \mathrm{~g} \mathrm{AFDM} \mathrm{m}^{-2} \mathrm{yr}^{-1}$. The outlier in
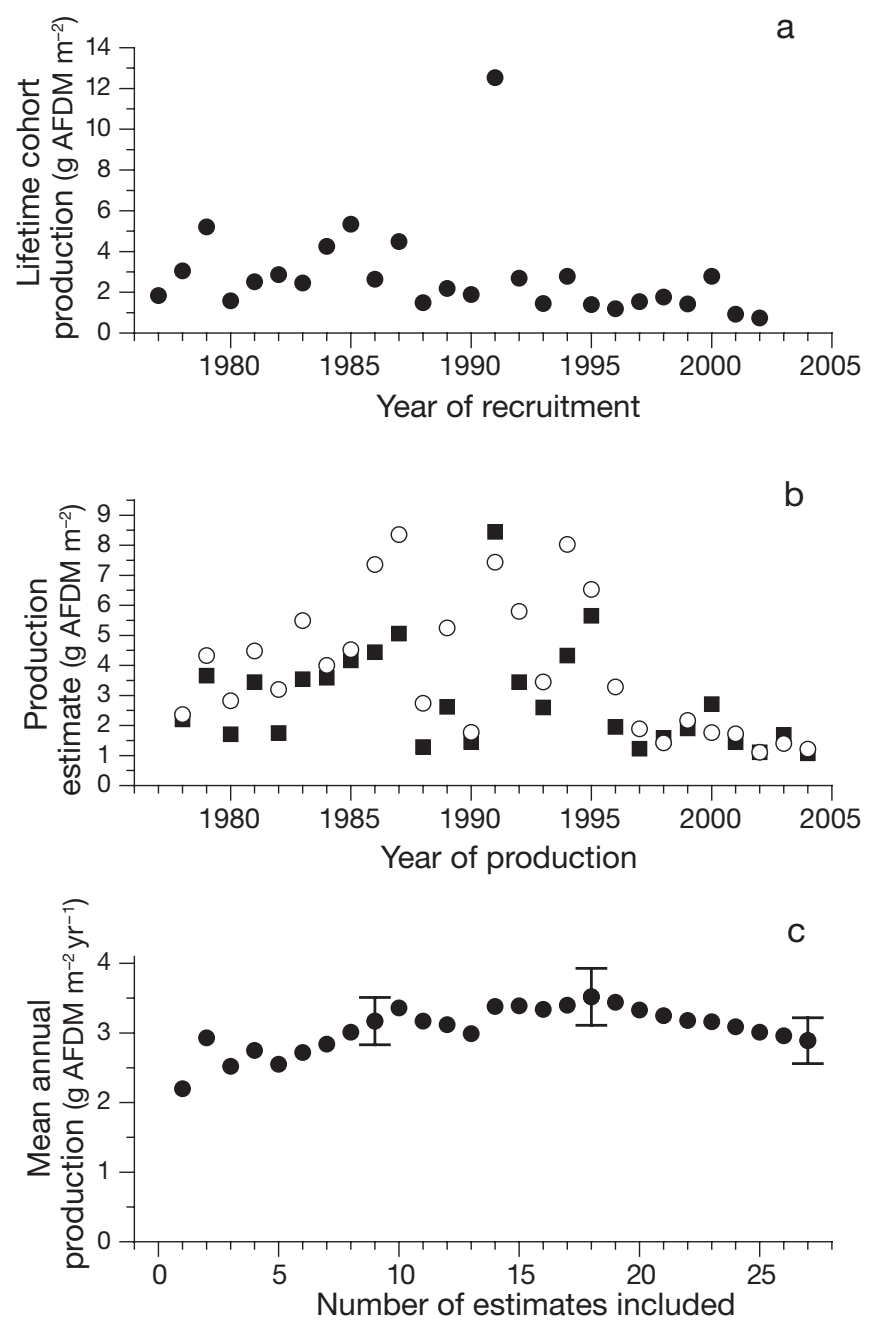

Fig. 6. Macoma balthica. Long-term series of successive estimates of somatic production of soft parts on Balgzand (mean of all sampling stations). (a) Net life-time production of 26 cohorts. Estimates include production in first growing season (set at $2 \times$ August spat biomass). (b) Growing-season (O) and net annual ( $\mathbf{\square})$ production of all cohorts present in each of 27 yr. (c) Cumulative mean total annual net production (shown by in b) after $1,2, \ldots 27$ yr of observation. SE were calculated for means of 9,18 and 27 successive annual estimates
Fig. 6a-the 1991 cohort-resulted from exceptionally successful recruitment in that year. If this 1 value is omitted, the remaining 25 values show a significant downward trend over time $(\mathrm{r}=-0.53, \mathrm{p}<0.01)$. In particular, the values of cohorts recruited in the last decade of the monitoring program were low (Fig. 6a), resulting in low values of annual production during this period (Fig. 6b). If the 27 annual values are (arbitrarily) divided into 3 groups of equal size, means for the last group (1996 to 2004) were less than half of those of the first 2 groups (1978 to 1986 and 1987 to 1995); furthermore, these differences were statistically significant (1st vs. 3rd group, $\mathrm{p}<0.01$; 2nd vs. 3rd group, $\mathrm{p}<0.02 ; 2$-sided Wilcoxon tests, $\mathrm{n}=9$ ).

Such long-term trends in production are more easily demonstrated by plots of cumulative means (Fig. 6c), which reveal an upward trend during the first 2 decades, followed by a downward trend during the last decade. These trends reflect a first decade of mostly increasingly productive cohorts followed by a period predominated by cohorts of low and declining production (Fig. 6a). Note in Fig. 6c that the cumulative means no longer showed much year-to-year variation by around the fifth year after the start of monitoring. Subsequent changes in cumulative means appear to have been influenced primarily by long-term trends in cohort production (and cohort strength; see below).

Several cohorts contributed to production in any given year, with maximum contributions made by young adult bivalves in their second and third year of life (see Fig. 4a). The animals in these age groups generally accounted for 60 to $80 \%$ of total annual production after the spat stage, but this proportion could increase to $\sim 90 \%$ when exceptionally strong cohorts (e.g. 1979, and particularly 1991) were present with abundant members of these age classes. In such years, the proportion of old adults (>34 mo old) in the total number of individuals was low (points marked 79 and 91 in Fig. 7a). These old adults contributed little to net annual production as a consequence of their large weight losses in winter (see Fig. 4a). The proportion of old adults was also low during the last $7 \mathrm{yr}$ (beginning in 1998) of the period of observation (Fig. 7a). This was not a result of the presence of strong cohorts of younger animals, but a consequence of exceptionally high adult mortality during this period, resulting in very low numbers of animals of more than $3 \mathrm{yr}$ of age.

Life time cohort production was strongly related to numerical density of the cohort early in life (Fig. 8). The first available estimates of recruit densities were obtained in August of each year, at a cohort age of $\sim 3 \mathrm{mo}$, and numbers at that time already predicted subsequent net production with good precision (Fig. 8a), with mean production per recruit being $6.6 \pm$ $0.4 \mathrm{mg}$ AFDM. This is an order of magnitude less than 

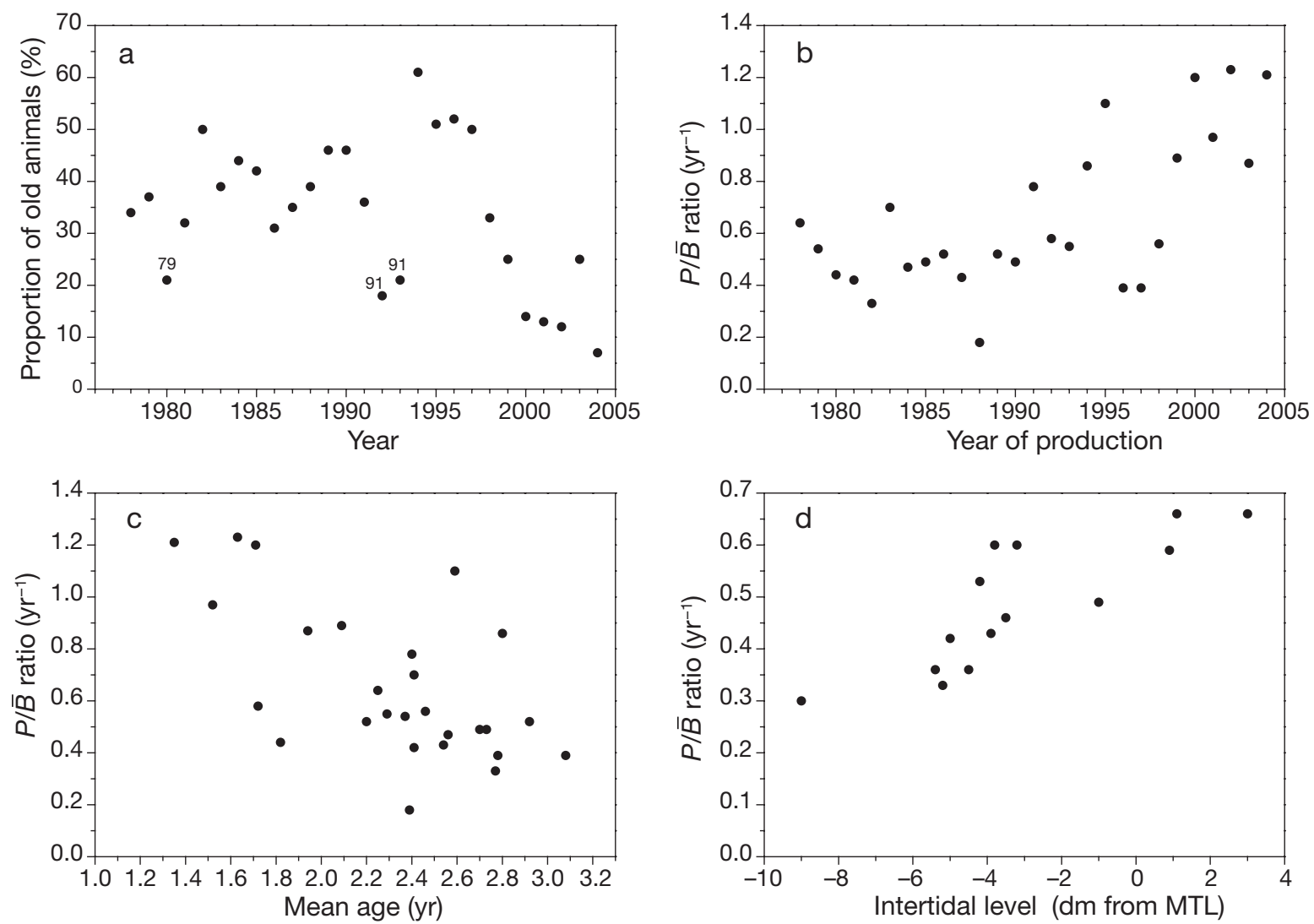

Fig. 7. Macoma balthica. (a) Successive annual estimates of proportion (\%) of old adults (age $\geq 34$ mo) in total number of individuals present at the start of the growing season (March). Values marked 79 and 91 refer to production years with a high contribution by the 2 strongest cohorts (recruited in 1979 and 1991, with numerical densities $>100 \mathrm{~m}^{-2}$ in March at 10 mo of age). (b) Successive estimates of the $P / \bar{B}$ ratio (where $P=$ net annual production of animals $\geq 10$ mo old and $B=$ mean annual biomass). (c) Relationship between mean age of all post-spat individuals at the start of the growing season (March) and observed $P / \bar{B}$ ratio in the subsequent full year. (d) Spatial variation (arranged intertidal level of 14 sampling stations, Stns C and 12 combined) of longterm mean annual $P / \bar{B}$ ratio calculated as a weighted average from $27 \mathrm{yr}$ sums of $P$ and $\bar{B}$ of adults (thus without SE). Best linear fit is: $(P / \bar{B}=0.59+[0.032 \times$ intertidal level $]$

maximum weights of soft parts of adults (shell length $\sim 2 \mathrm{~cm})$. The reason for this difference is that by far the majority of individual recruits did not reach an age at which to substantially contribute to production. The following estimate of recruit density was made in March, at a cohort age of $\sim 10 \mathrm{mo}$, when the bivalves were still of spat size but had survived their first winter (and had not migrated to areas outside Balgzand). By then, the much lower numbers of recruits subsequently produced significantly larger amounts per individual: on average, $32 \pm 1.4 \mathrm{mg}$ AFDM (Fig. 8b). Initial recruit densities (in August or March) explained $>80 \%$ of variability in subsequent cohort production (regression analysis).

At first sight, the relationships between recruit densities and subsequent life-time cohort production values shown in Fig. 8 suggest low and inconsistent variability in production values per recruit. However, this was not so for production per recruit in August, which declined significantly with increasing cohort strength (Fig. 9a; p =0.01, regression analysis), suggesting a negative density-dependence effect on production. In contrast, the much higher production per recruit of recruits still present in March (Fig. 9b) did not significantly change with recruit density $(p=0.4)$. This difference can be accounted for by the substantial reductions in recruit numbers between August and March, which were generally larger in strong than in weak cohorts. In the strongest cohorts, $<20 \%$ of August recruits were still present on Balgzand in March, whereas in smaller cohorts this proportion was usually $>20 \%$ (Fig. 9c).

The magnitude of the growth production of a population in any year is determined by the numbers of individuals involved (i.e. by numerical density) and their growth rates (net weight gain, i.e. weight gain in the growing season minus weight loss in the remainder of the year). To explain between-year variability in net 

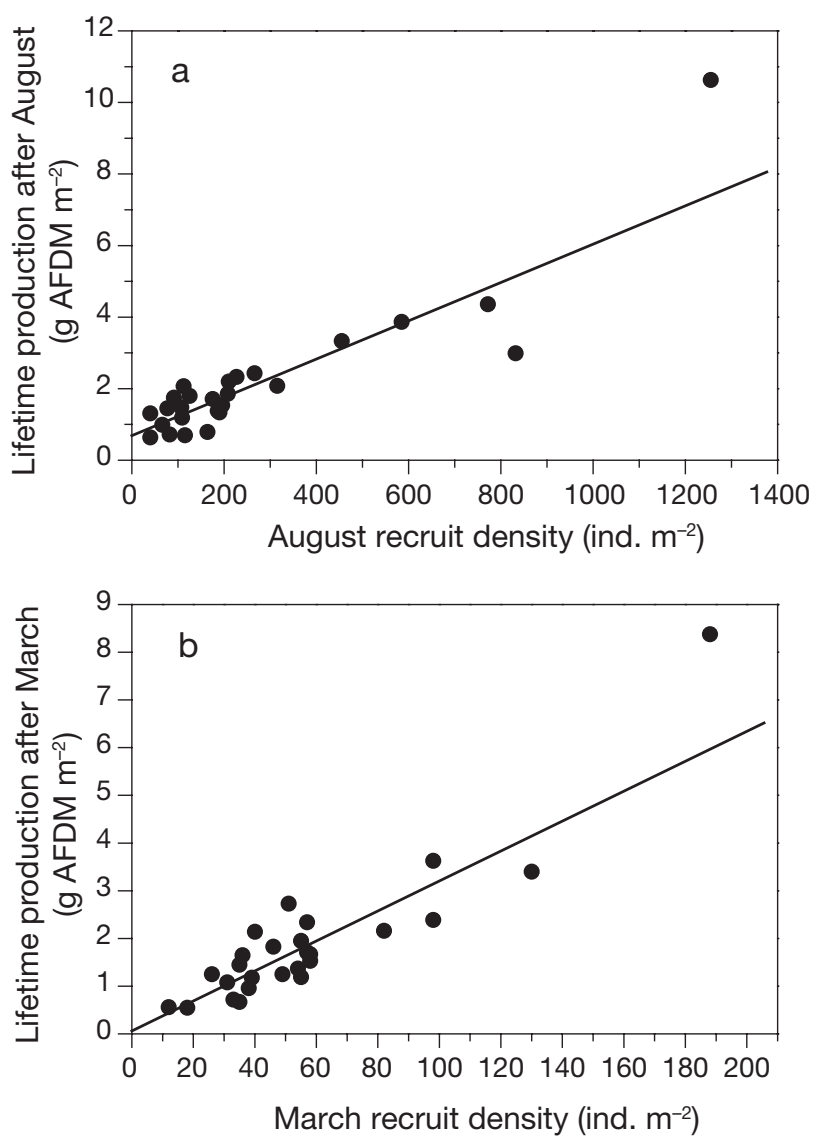

Fig. 8. Macoma balthica. Dependence of subsequent lifetime net cohort production of soft parts $\left(P, \mathrm{~g} \mathrm{AFDM} \mathrm{m}^{-2}\right)$ on initial recruit numbers $\left(D\right.$, ind $\left.\mathrm{m}^{-2}\right)$. Data of 26 cohorts recruited between 1977 and 2002, inclusive. (a) Recruit densities in August (age $\sim 3 \mathrm{mo})$. Linear fit: $P=0.68+0.0054 D(\mathrm{n}=26, \mathrm{r}=$ $0.92, \mathrm{p}<0.0001)$, or $P=0.0066 D$ if forced through origin. (b) Recruit densities in March (age $\sim 10$ mo). Linear fit: $P=0.06$ $+0.031 D(\mathrm{n}=26, \mathrm{r}=0.92, \mathrm{p}<0.0001)$, or $P=0.032 D$ if forced through origin

production $\left(P, \mathrm{~g} \mathrm{AFDM} \mathrm{m}^{-2} \mathrm{yr}^{-1}\right)$, we studied the contribution of 3 independent factors by way of a multicorrelation test (using the general linear model function in SYSTAT). These factors were the total number of all Macoma balthica individuals present at the start of the growing season in March $\left(N\right.$, ind. $\left.\mathrm{m}^{-2}\right)$, mean individual weight gain between March and August $\left(\delta G, \mathrm{mg}\right.$ AFDM ind $\left.^{-1}\right)$ in $1 \mathrm{yr}$ old individuals as an index of the growth rate in any year, and mean water temperature during the subsequent winter $\left(T,{ }^{\circ} \mathrm{C}\right)$ as a predictor of weight loss in the remainder of the year following the growing season (see Fig. 5). Together, these 3 factors explained $63 \%$ of the variance in $P(\mathrm{n}=$ 27: 1978 to 2004 inclusive), and each of these 3 factors contributed significantly to the model. Among the individual factors, $N$ made the most important contribution to the model $(37 \%, r=+0.61, p<0.001)$. The contribu-
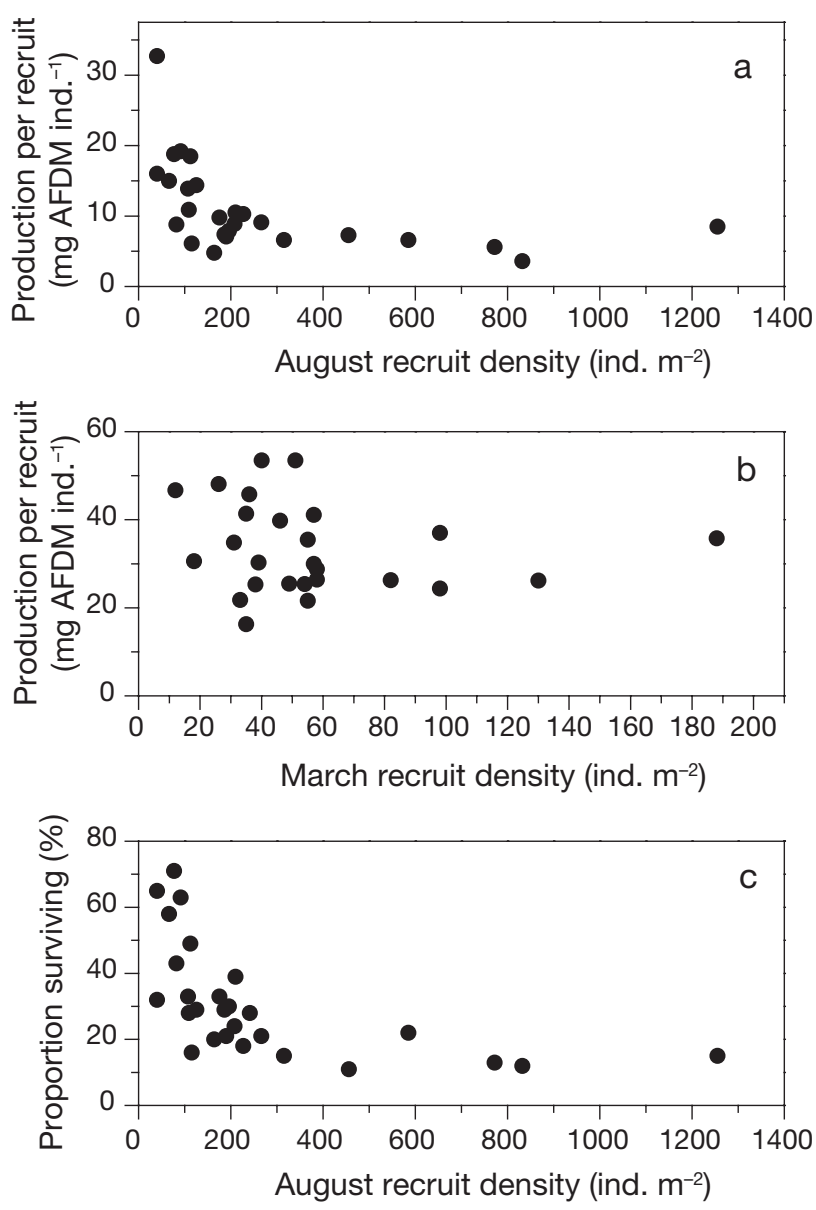

Fig. 9. Macoma balthica. Relationship between initial spat density $\left(D\right.$, ind $\left.\mathrm{m}^{-2}\right)$ in (a) August and (b) March and subsequent production per recruit $\left(P, \mathrm{mg}\right.$ AFDM ind $\left.{ }^{-1}\right)$. Values are mean of 15 Balgzand stations for 26 cohorts recruited between 1977 and 2002, inclusive. (c) Relationship between recruit density in August (age $\sim 3 \mathrm{mo}$ ) and proportion of these recruits still alive on Balgzand half a year later at the start of the second growing season in March (expressed as \%, i.e. 100 $\times$ [sum at 15 stns in March $\div$ sum in preceding August]). Best linear fits: (a) $P=14-0.0105 D(\mathrm{r}=-0.49, \mathrm{n}=26, \mathrm{p}=0.01)$; (b) $P=36-0.046 D(\mathrm{r}=-0.17, \mathrm{n}=26, \mathrm{p}=0.4)$; (c) \% survival = $40-0.033 D(\mathrm{r}=-0.55, \mathrm{n}=26, \mathrm{p}=0.002)$

tion of $\delta G(18 \%)$ was also significant $(\mathrm{r}=+0.42, \mathrm{p}<$ $0.05)$, whereas $T$ contributed least: $12 \%(\mathrm{r}=-0.34, \mathrm{p}<$ 0.1 . Note that the sum of the separate contributions (67\%) was close to the value of the 3 factors combined ( $63 \%$; see above). Density and growth were not mutually correlated $(\mathrm{r}=-0.01)$.

\section{Local variation in production}

Long-term mean annual production values varied significantly (1-way ANOVA, p < 0.0001) among the individual Balgzand sampling stations. Sites with high 
and low production were not randomly scattered over the area. Low production values were found particularly at the lowest intertidal levels, i.e. near the low-water level and far offshore (Figs. 1 \& 10a). The correlation between station level and mean annual net production was statistically significant $(r=+0.57, \mathrm{n}=14, \mathrm{p}<0.05)$. The best linear fit showed an increase of $0.13 \mathrm{~g}$ AFDM in mean annual production $\mathrm{m}^{-2}$ per $\mathrm{dm}$ increase in intertidal level, but may not be continuous; the ( $\sim 4$-fold) increase appears to be limited to the lower part of the intertidal range-from the low-water line up to MTL. At higher levels, no trend is apparent (Fig. 10a).

Mean annual recruitment (26 yr mean number of spat-sized Macoma balthica $\mathrm{m}^{-2}$ in March) showed a similar and even more consistent relationship with intertidal level, continuing above MTL (Fig. 10b). Spatial variation in mean local recruit densities $D$ (as shown in Fig. 10b) explained a significant part of the observed spatial variation in mean production (as shown in Fig. 10a), i.e. $P=0.9+0.015 D\left(\mathrm{r}^{2}=0.59, \mathrm{n}=\right.$ $14, \mathrm{p}<0.01$, linear regression). Nevertheless, mean life time production (after March) per recruit recorded in
March also varied significantly among stations (1-way ANOVA, p < 0.0001) (Fig. 10c), but in the reverse: maximum values were observed in the lowest intertidal areas. The negative relationship between production per recruit and intertidal height was highly significant ( $\mathrm{r}=-0.87, \mathrm{n}=14, \mathrm{p}<0.0001$, linear regression). Thus, relatively low production per recruit may explain why annual production was not higher at the highest intertidal levels, notwithstanding high recruit densities.

The above relationships are shown for production after the first winter of life, because distribution patterns of Macoma balthica drastically change during their first winter (Beukema \& De Vlas 1989, Beukema 1993, Hiddink \& Wolff 2002, Beukema \& Dekker 2003) when substantial parts of the spat migrate from high to low areas and thus complete their production at different stations to those where they lived during their first summer. As Fig. 3 of Beukema \& De Vlas (1989) demonstrates, this winter migration will not yet have been completed by the time that annual sampling is conducted in March (animals would still be leaving the higher stations and arriving at the lower stations);
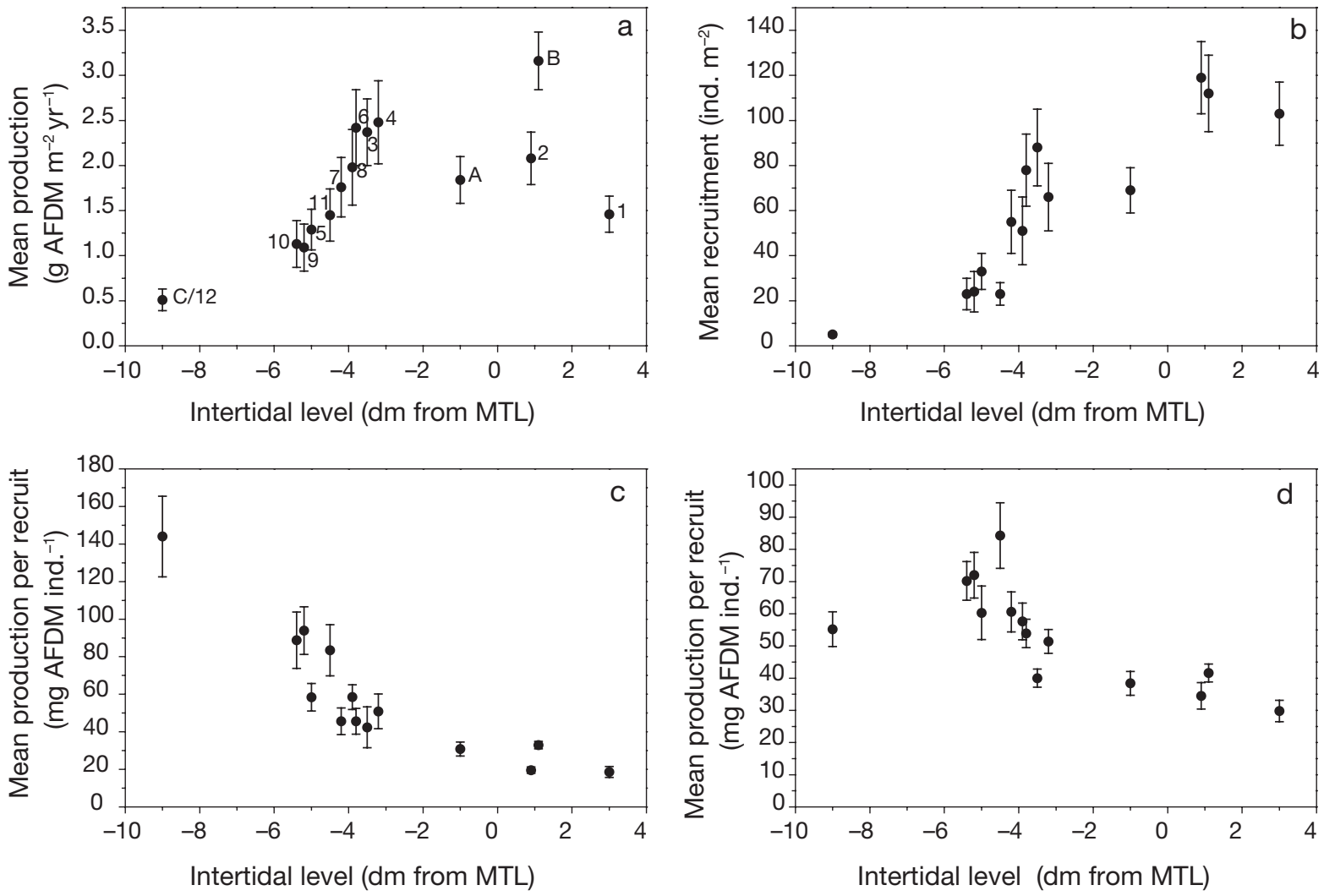

Fig. 10. Macoma balthica. Relationship between intertidal height of 14 sampling stations (Stns C and 12 combined) and (a) longterm mean somatic production of soft parts (production achieved after $\sim 10$ mo only; stations marked as in Fig. 1); (b) long-term mean density of recruits in March, i.e. at $\sim 10$ mo of age; (c) mean life-time production per recruit after the first March of their life (i.e. excluding production at spat size, at an age of $<10 \mathrm{mo}$ ); (d) as in (c) but after August of the second year of life (at an age of $>15 \mathrm{mo}$ ). All parts of Fig. 10: $1 \mathrm{SE}, \mathrm{n}=26$ (cohorts recruited 1977-2002) 
therefore, we also used the numerical densities observed half a year later (in August, at an age of $15 \mathrm{mo}$ ) to compare production values per recruit among the various stations (Fig. 10d). The relationship with intertidal level remained essentially similar: again, a significantly negative relationship between production per recruit and intertidal level was observed ( $\mathrm{r}=-0.71, \mathrm{p}<0.005)$.

The reduced total Balgzand production rates observed within the last part of the monitoring program (Fig. 6b) were observed at nearly all sampling stations except those at the 3 highest stations closest to the SW shore of Balgzand (Stns A, 1 \& 2, see Fig. 1). Likewise, recruit numbers did not decline at these high stations.

\section{Annual $P / \bar{B}$ ratio values}

$P / \bar{B}$ ratio values are bound to decline with size and age of animals, simply because the relative annual weight gain of individuals declines with size and thus
$P$ (newly produced biomass) becomes a declining proportion of $\bar{B}$ (existing biomass). Consequently, nearly constant $P / \bar{B}$ values can be expected only in populations with low variability in age composition. In the Balgzand population of Macoma balthica, mean annual $P / \bar{B}$ ratio values declined from $\sim 1.2 \pm 0.1 \mathrm{yr}^{-1}$ in the 2 nd year of life to $\sim 0.2 \pm 0.1 \mathrm{yr}^{-1}$ at old age (Fig. $4 \mathrm{~b}$ ), with intermediate values of $\sim 0.7$ and $\sim 0.4 \mathrm{yr}^{-1}$ observed during the 3rd and 4 th year of life, respectively. For the entire adult population (age groups $>10$ mo old), mean annual $P / \bar{B}$ ratio values were highly variable and ranged from $\sim 0.2$ to $\sim 1.2$ (Fig. $7 \mathrm{~b}$ ), with a $27 \mathrm{yr}$ mean of $0.66 \pm 0.06 \mathrm{yr}^{-1}(\mathrm{n}=27,1 \mathrm{SE})$. The mean value of 0.5 given in Table 1 is a weighted average (27 yr sum of 14-station means of net annual $P$ divided by 27 yr sum of 14-station means of mean annual $B$ ), and differs from the above-mentioned mean of 0.66 owing to the fact that the higher $P / \bar{B}$ ratio values for individual years shown in Fig. $7 \mathrm{~b}$ generally referred to years with low values of $P$ and $\bar{B}$.

Table 1. Macoma balthica. Published estimates of mean annual somatic soft-part production $\left(P\right.$ or $\left.E, \mathrm{~g} \mathrm{AFDM} \mathrm{m}^{-2} \mathrm{Yr}^{-1}\right)$ with estimates of annual mean biomass $\left(\bar{B}, \mathrm{~g} \mathrm{AFDM} \mathrm{m}^{-2}\right)$ and $P / \bar{B}$ or $E / \bar{B}$ ratios (both $\mathrm{yr}^{-1}$ ) in various intertidal regions. Method: estimates were either sums of growth increments $(P)$ or sums of removals $(E)$

\begin{tabular}{|c|c|c|c|c|c|c|c|}
\hline Area (country) & Method & No. of years & No. of stations & $P$ or $E$ & $\bar{B}$ & $P(E) / \bar{B}$ & Source \\
\hline $\begin{array}{l}\text { Wadden Sea } \\
\text { (Netherlands) }\end{array}$ & $\begin{array}{l}P \\
E\end{array}$ & $\begin{array}{l}2 \\
2\end{array}$ & $\begin{array}{l}15 \\
15\end{array}$ & $\begin{array}{l}1.5 \\
2.0\end{array}$ & $\begin{array}{l}3.2 \\
3.2\end{array}$ & $\begin{array}{l}0.5 \\
0.6\end{array}$ & Beukema (1971) \\
\hline $\begin{array}{l}\text { Petpeswick Inlet } \\
\text { (Canada) }\end{array}$ & $\begin{array}{l}P \\
E\end{array}$ & $\begin{array}{l}1 \\
1\end{array}$ & $\begin{array}{l}1 \\
1\end{array}$ & $\begin{array}{l}1.9 \\
2.1\end{array}$ & $\begin{array}{l}1.3 \\
1.3\end{array}$ & $\begin{array}{l}1.5 \\
1.6\end{array}$ & Burke \& Mann (1974) \\
\hline $\begin{array}{l}\text { Lynher estuary } \\
\text { (England) }\end{array}$ & $P$ & 1 & 1 & 0.3 & 0.3 & 0.9 & Warwick \& Price (1975) \\
\hline $\begin{array}{l}\text { Ythan estuary } \\
\text { (Scotland) }\end{array}$ & $P$ & 1 & 1 & 5.7 & 2.8 & 2.1 & Chambers \& Milne (1975) \\
\hline $\begin{array}{l}\text { Grevelingen } \\
\text { (Netherlands) }\end{array}$ & $P$ & 1 & 6 & $0.6^{\mathrm{a}}$ & $1.0^{\mathrm{a}}$ & $0.6^{\mathrm{a}}$ & Wolff \& de Wolf (1977) \\
\hline $\begin{array}{l}\text { Gironde estuary } \\
\text { (France) }\end{array}$ & $P$ & 1 & 3 & $1.1^{\mathrm{b}}$ & $2.2^{\mathrm{b}}$ & $0.8^{\mathrm{b}}$ & Bachelet (1982) \\
\hline $\begin{array}{l}\text { Forth estuary } \\
\text { (Scotland) }\end{array}$ & $\begin{array}{l}P \\
P\end{array}$ & $\begin{array}{l}1 \\
1\end{array}$ & $\begin{array}{l}14 \\
14\end{array}$ & $\begin{array}{l}1.1^{\mathrm{c}} \\
0.9^{\mathrm{d}}\end{array}$ & $\begin{array}{l}3.2^{\mathrm{c}} \\
1.9^{\mathrm{d}}\end{array}$ & $\begin{array}{l}0.4^{\mathrm{c}} \\
0.5^{\mathrm{d}}\end{array}$ & Elliott \& McLusky (1985) \\
\hline $\begin{array}{l}\text { Cumberland Basin } \\
\text { (Canada) }\end{array}$ & $P$ & 1 & 2 & 0.5 & 0.6 & 0.8 & Cranford et al. (1985) \\
\hline $\begin{array}{l}\text { Shepody Bay } \\
\text { (Canada) }\end{array}$ & $P$ & 1 & 3 & 3.5 & 4.3 & 0.8 & Cranford et al. (1985) \\
\hline $\begin{array}{l}\text { Wadden Sea } \\
\text { (Netherlands) }\end{array}$ & $\begin{array}{l}E \\
E\end{array}$ & $\begin{array}{l}24 \\
25\end{array}$ & $\begin{array}{l}11 \\
11\end{array}$ & $\begin{array}{l}1.6 \\
2.4\end{array}$ & & & $\begin{array}{l}\text { Van der Meer et al. (2001a) } \\
\text { Van der Meer et al. (2001b) }\end{array}$ \\
\hline $\begin{array}{l}\text { Wadden Sea } \\
\text { (Netherlands) }\end{array}$ & $\begin{array}{l}P^{\mathrm{e}} \\
P\end{array}$ & $\begin{array}{l}27 \\
27\end{array}$ & $\begin{array}{l}15 \\
15\end{array}$ & $\begin{array}{l}1.9 \\
2.9\end{array}$ & $\begin{array}{l}3.6 \\
3.8\end{array}$ & $\begin{array}{l}0.5 \\
0.8\end{array}$ & Present paper \\
\hline \multicolumn{8}{|c|}{$\begin{array}{l}\text { bMean of } 3 \text { local values ranging from } 0.5 \text { to } 2.1(P), 0.6 \text { to } 5.4(\bar{B}) \text {, and } 0.4 \text { to } 1.3(P / \bar{B}) \\
\text { 'Mean values for } 1975-6 \text { of } 14 \text { local values ranging from }-0.3 \text { to }+4.4(P), 0.8 \text { to } 9.1(\bar{B}) \text {, and }-0.4 \text { to }+0.5(P / \bar{B}) \\
\text { d Mean values for } 1976-7 \text { of } 14 \text { local values ranging from } 0.1 \text { to } 2.6(P), 0.5 \text { to } 5.6(\bar{B}) \text {, and } 0.1 \text { to } 1.1(P / \bar{B}) \\
\text { e'Spat-sized animals }(<10 \text { mo old) excluded }\end{array}$} \\
\hline
\end{tabular}


The annual values shown in Fig. $7 \mathrm{~b}$ showed a significantly increasing trend (correlation with time: $\mathrm{r}=$ $+0.66, \mathrm{n}=27, \mathrm{p}<0.001)$. For the most part, this trend could be explained by high values during the last 6 yr when the population was particularly depleted of old individuals (Fig. 7a), which are characterized by low $P / \bar{B}$ ratio values (Fig. $4 \mathrm{~b}$ ). In the last $6 \mathrm{yr}$ of our observations, old individuals became rare as a consequence of enhanced mortality of adults (the cause of which is unknown). Age composition of the population explained a substantial part of the variability in annual $P / \bar{B}$ ratio values. The relationship between annual $P / \bar{B}$ and mean age $(A)$ at the start of the growing season in March was significantly negative (Fig. 7c: $\mathrm{r}=-0.61, \mathrm{n}=27, \mathrm{p}<0.001$ ), and the best linear fit is expressed by $P / \bar{B}=1.56-0.39 A$.

$P / \bar{B}$ ratio values were found to vary from place to place in a consistent manner, increasing with increasing height of the sampling site (Fig. 7d) ( $\mathrm{r}=0.82, \mathrm{n}=$ $14, p<0.001)$. Thus, for the same biomass, annual production was on average higher at the high near-coast tidal flats than at the low off-shore tidal flats.

\section{DISCUSSION}

\section{Methodological problems}

Two basically different methods are available for estimating secondary production in populations (Van der Meer et al. 2005): the growth-increment summation method (using successive data on numerical density and mean individual weights) and the elimination (sums of removals) method (using data series on biomass and mortality rate). In the long term, the 2 methods yield equal estimates of mean annual production (see below for a comparison of Balgzand estimates) and lifetime cohort production. However, for individual years, the 2 methods do not yield similar estimates (as growth must precede elimination: in long-lived individuals it can take years before weight gain is removed by a consumer). In the present study we opted for the growth-increment summation method, because the estimates obtained can be linked directly to growing conditions such as algal concentrations and primary production. For the western part of the Wadden Sea, long data series on algal concentrations and annual primary production exist (Cadée \& Hegeman 2002) and we intend to use these data in a later study of relationships with the secondary production of bivalves on Balgzand.

In order to estimate net annual production, the 2 seasonal estimates of each year should be summated. In a sense, this is a matter of course as it provides the annual value that is on average equal to that obtained by the elimination method. However, one could argue that for some purposes the semi-annual (growing season only) values are more appropriate, e.g. to make comparisons with food supply. Outside the growing season, production values will depend largely on conditions that have nothing to do with food (winter temperature; Fig. 5), and incorporation of values from this season might spoil relationships between primary and secondary production. Therefore, we present estimates of both semi-annual and annual production of Macoma balthica (Fig. 6b).

To avoid biased estimates resulting from seasonal weight cycles, sampling should be executed frequently or, if this is too laborious, within well chosen annual periods. As we explained earlier (Beukema \& Dekker 2006), twice-annual sampling at maximum and minimum individual weights would be preferable, but it is theoretically feasible to obtain an unbiased estimate by sampling once annually about half-way between the peak and trough of individual weight. The exact timing should be assessed by following some annual cycles of changes in individual weights and numbers. We would prefer twice-annual sampling at 2 periods characterized by slow weight changes that would allow the longer sampling periods needed for largescale studies. The comparison we made of such estimates with (undoubtedly more accurate) sums of monthly estimates revealed only minor differences (on average $2 \%$ ). Therefore, we judge the applied procedure of estimating production from twice-annual sampling to be adequate. Any sampling conducted on a more frequent basis, aimed at obtaining estimates of higher quality, would then have been a waste of effort.

\section{Temporal variability in production}

Macoma balthica production on the tidal flats of Balgzand proved to be highly variable, both intra- and interannually (Figs. 3 \& 6b).

\section{Seasonal variation}

Short-term month-to-month variation in production (Fig. 3) reflected the annual growth pattern (as observed in detail in 1968 and 1969; Fig. 2), which in this area is characterized by a short annual growing season in spring and part of summer. In years subsequent to 1968 and 1969, similar seasonal patterns were observed in Wadden Sea populations of Macoma balthica (see Beukema \& Desprez 1986). Short annual growing seasons at roughly the same time of year were also observed for several other bivalve species in the Wad- 
den Sea (Zwarts 1991, Dekker \& Beukema 1993, 1999, Dankers \& Zuidema 1995, Honkoop \& Beukema 1997). Shifts from positive to negative production (growth) are determined by the net result of energy intake and expenditure. Intake will increase with food supply and feeding activity, expenditure with temperature and (feeding) activity. During the course of summer, food concentrations on Balgzand decline (Hummel 1985a, Cadée 1986) and temperature and respiration rise (Hummel 1985b), leading rapidly to a negative energy budget during summer, mostly in July (Hummel 1985b). The exact timing of this shift appears to depend on temperature (Beukema et al. 1985). Furthermore, old animals show earlier shifts than do young adults (Fig. 2), whereas spat-sized animals continue growth for long periods in summer and autumn. Adults lose substantial parts of their weight for long annual periods, particularly when winter is mild (Fig. 5). The dependence of over-winter weight losses on food concentration and water temperature was not only observed in the field, but also experimentally proven by Honkoop \& Beukema (1997). In late winterearly spring, food concentrations in the area (Cadée 1986, Beukema \& Cadée 1996) and food intake rise together with respiration, but the difference between intake and expenditure of energy becomes positive in March (Hummel 1985b). This shift appears to occur earlier in March in mild than in cold winters (Beukema et al. 1985). The exceptional situation in early 1991, with regard to high food supply that lead to an early start of the growing season (Beukema \& Cadée 1996), is evidence that changes in food concentration trigger the spring shift as well.

Because we sampled in August in all years irrespective of the summer conditions, we had to correct our estimates of growing-season production for early-summer weight losses (on the basis of July water temperatures) in order to avoid underestimates of growing-season production. Subsequent weight losses between the end of one growing season and the start of the next were substantial, particularly in old individuals (Fig. 2) and during mild winters (Fig. 5), as was also observed by Zwarts (1991) and Honkoop \& Beukema (1997). Resulting net annual production values were invariably positive for the first $4 \mathrm{yr}$ of life of Macoma balthica. However, at greater ages, some negative net values were recorded (but were nonetheless rare: $<10 \%$ of the total of $\sim 100$ net values for $\sim 20$ cohorts and 5 age groups). An unknown portion of these negative values may have arisen from sampling errors, but true negative values can also occur (as observed by Cusson \& Bourget 2005a for sub-populations of mussels). Negative values were particularly numerous in the older age classes in the production year 1988. This year included the mildest winter (1988-1989) of the period of obser- vation, with high individual weight losses (see Fig. 5) that surpassed the weight gains of the previous growing season in these age classes.

The above regular seasonal pattern of one annual season of growth and one of loss appears to occur all over the Wadden Sea, but may be different in other areas. In the Ythan estuary in Scotland, Chambers \& Milne $(1975,1979)$ found a similar annual pattern, as did Wolff \& De Wolf (1977) in the Grevelingen estuary (southwest of The Netherlands). However, in France, Bachelet (1982) observed 2 annual growth periods in the Gironde Estuary, as did Beukema \& Desprez (1986) in the Seine estuary. Besides the usual spring season (February to June), a second period of weight gain was found to occur in France in autumn - probably related to high phytoplankton concentrations found at this time of the year in French estuaries but not in the Wadden Sea. The weight-loss season thus appears to be several months shorter in France than in more northern areas, and hence negative production constitutes a smaller proportion of positive growing-season production (cf. Fig. 2 of the present study with Fig. 3 of Bachelet 1982). Nevertheless, annual $P$ values were not higher in the Gironde area than in the Wadden Sea (Table 1), owing to relatively low numerical densities in the former area.

Production studies of species with a seasonal weight cycle involving considerable weight loss outside the growing season will yield biased estimates of annual production if the sampling schedule is not adapted to such cycles. For example, Burke \& Mann (1974) restricted their sampling of bivalves and gastropods to the period between April and December, and such restriction is bound to result in an overestimate of annual production if the animals loose weight between December and April. Some other authors (Cranford et al. 1985, Van der Meer et al. 2001a) did not actually measure weights of soft parts in more than 1 season, but converted lengths to weights by a condition factor assessed in a single season. If this was assessed in winter (at minimal weights of soft parts), then production estimates are bound to result in underestimates of true annual production. The correct estimate (on the basis of both winter and summer data of individual weights) of Balgzand production published by Van der Meer et al. (2001b) is indeed $\sim 50 \%$ higher than the estimate of Van der Meer et al. (2001a) that was based on winter data only (see Table 1). If we were to compare the (correct) estimate of Van der Meer et al. (2001b) of $2.4 \mathrm{~g}$ AFDM m ${ }^{-2} \mathrm{yr}^{-1}$ with ours of $2.9 \mathrm{~g} \mathrm{AFDM} \mathrm{m}^{-2} \mathrm{yr}^{-1}$, then the 2 estimates should be restricted to the overlapping parts of the 2 periods of observation, resulting in mean values of 2.6 and $3.2 \mathrm{~g} \mathrm{AFDM} \mathrm{m}^{-2} \mathrm{yr}^{-1}$, respectively, for the 1978 to 1998 period. The remaining difference is mainly due to the different way that (unknown) pro- 
duction before the first sampling date in August was accounted for, viz. either as 1 (Van der Meer et al. $2001 \mathrm{~b}$ ) or as 2 (present study) times the August spat biomass of on average $0.4 \mathrm{~g} \mathrm{AFDM} \mathrm{m}^{-2} \mathrm{yr}^{-1}$. The thus comparable values of 3.0 and $3.2 \mathrm{~g} \mathrm{AFDM} \mathrm{m}^{-2}$ (both calculated with a spat production of $2 \times$ August spat biomass) should be (nearly) equal, because in the long term the elimination and growth summation method (used by Van der Meer et al. 2001b and the present authors, respectively) should yield identical mean values (cf. Van der Meer et al. 2005). The remaining difference is indeed small and can be accounted for by the different number of sites used in each study (11 vs. 15) and a slight difference in mean biomass at the start and end of the observation period.

\section{Year-to-year variation}

In the present study, estimates of net annual production of Macoma balthica fluctuated from year to year by an order of magnitude (Fig. 6b). Nevertheless, within $<10$ yr of monitoring, a long-term average was obtained that was close to the long-term mean of the entire $27 \mathrm{yr}$ study (Fig. 6c). The declining trend in annual production estimates observed over the last decade means that it would be impossible to obtain a more stable cumulative mean estimate by lengthening the monitoring period. Note that an initial estimate of $1.5 \mathrm{~g} \mathrm{AFDM} \mathrm{m}^{-2}$ $\mathrm{yr}^{-1}$ for net production by the adult population on Balgzand published more than 30 yr ago by Beukema (1971), which was based on only 2 yr of observation, happens to be close to the present comparable longterm mean estimate of $1.9 \mathrm{~g} \mathrm{AFDM} \mathrm{m}^{-2} \mathrm{yr}^{-1}$ for postspat production. Ironically, at that time, J. Beukema decided on the basis of substantial observed year-to-year differences in numerical densities, growth rates and production (of $M$. balthica and other bivalve species) that he had to start a long-term sampling program in order to obtain more representative estimates of these population parameters in the Balgzand tidal-flat area.

Studies of a considerable ( $>10 \mathrm{yr}$ ) length on production of zoobenthos appear to be rare. No such studies of Macoma balthica appear to be available for any area other than Balgzand (Table 1); in all cases, studies conducted in other areas lasted 1 yr or less. Consequently, these studies were probably not of sufficient length to obtain representative values of this species' production or $P / \bar{B}$ ratio in any area. The long-term Balgzand somatic-production estimates of 1.9 and $2.9 \mathrm{~g}$ AFDM $\mathrm{m}^{-2} \mathrm{yr}^{-1}$ (excluding and including production by spatsized animals, respectively) are well within the range of estimates obtained in other areas (Table 1: 0.3 to 5.7, with an 8-area mean of $1.8 \mathrm{~g} \mathrm{AFDM} \mathrm{m}^{-2} \mathrm{yr}^{-1}$ ) and are not too dissimilar to the overall 8-area mean.
The Balgzand production estimate of almost $3 \mathrm{~g}$ AFDM m ${ }^{-2} \mathrm{yr}^{-1}$ does not fully account for total organic production by Macoma balthica, because it does not include (1) siphon growth to compensate for siphon nibbling, (2) gamete production or (3) the organic content of shells, as elaborated below

(1) In 1975, De Vlas (1985) estimated losses of Macoma balthica siphon tissue to nibbling epibenthic predators to amount to no less than $0.9 \mathrm{~g} \mathrm{AFDM} \mathrm{m}^{-2}$ (mean of 4 Balgzand sampling sites). If this amount were representative for other years and for the total Balgzand, it would mean that the present estimate of total somatic soft-part production of $\sim 3 \mathrm{~g} \mathrm{AFDM} \mathrm{m}^{-2}$ $\mathrm{yr}^{-1}$ should be raised by this value, because the nibbled material is immediately regenerated and excluded from our estimate of production.

(2) Assessment of gamete production from (even frequent) field observations of weight change is not feasible for species that spawn during the growing season: any observed change in mean individual weight is a net result of weight gain by somatic growth and weight loss by gamete release, the proportion of each of which is unknown. Gamete production should be assessed separately by the collection of eggs and sperm, and the resulting estimate added to seasonal or annual estimates of somatic production. Some estimates of gamete production are available for the Balgzand Macoma balthica population. Assessed in the laboratory as a sum of several successive spawning events, gamete production by individuals collected on Balgzand amounted to $\sim 25 \%$ of this species' soft-part body weight (De Wilde \& Berghuis 1978), which-when extrapolated-would result in long-term mean gamete production of $\sim 0.8 \mathrm{~g} \mathrm{AFDM} \mathrm{m}{ }^{-2} \mathrm{yr}^{-1}$. Hummel (1985b) estimated gamete production of the Balgzand population as $0.13 \mathrm{~kJ}$ ind. ${ }^{-1}$, or $\sim 20 \%$ of his estimate of growing-season somatic production $\left(0.63 \mathrm{~kJ}\right.$ ind..$\left.^{-1}\right)$. Such an estimate would amount to gamete production of $0.2 \times$ $3.5=0.7 \mathrm{~g} \mathrm{AFDM} \mathrm{m}^{-2} \mathrm{yr}^{-1}$. In an elaborate study of reproductive output by $M$. balthica at Balgzand, Honkoop et al. (1999) estimated individual egg production to be 0 to $33 \%$ of the biomass $\left(\mathrm{g}\right.$ AFDM m ${ }^{-2}$ ) at the beginning of the spawning season (late Marchearly April), depending on body-mass index (BMI: total weight of soft parts [mg] AFDM divided by the third power of shell length [cm]). As the long-term mean of March BMI values on Balgzand was $\sim 8 \mathrm{mg} \mathrm{cm}^{-3}$ (Beukema et al. 2001b), mean weights of spawned eggs would amount to $\sim 15 \%$ of total adult biomass. Assuming that males produce similar amounts of sperm in terms of weight, mean gamete production would amount to $0.4 \mathrm{~g}$ AFDM m${ }^{-2} \mathrm{yr}^{-1}$ (long-term mean biomass of adults in early spring was $\sim 2.4 \mathrm{~g} \mathrm{~m}^{-2}$ ). We consider the latter estimate to be the most sound, because it accounts for between-year variation. A 
higher estimate of (on average) $37 \%$ of somatic production by Bachelet (1982) was not discussed here, because we do not think that it was obtained by an appropriate method (viz. summed weight losses during the spawning season).

(3) Mean shell production on Balgzand amounted to $13 \mathrm{~g} \mathrm{~m}^{-2} \mathrm{yr}^{-1}$ from 1969 to 1979 (Beukema 1980), which was about $5 \times$ greater than soft-part production during the same period. As Macoma balthica shells may contain $\sim 1 \%$ of organic matter, another 0.1 or $0.2 \mathrm{~g}$ should be added to the annual production of organic matter.

Thus, total annual net production might amount to a long-term average of at least $2.9+0.9+0.4+0.1=4.3 \mathrm{~g}$ organic material $\mathrm{m}^{-2} \mathrm{yr}^{-1}$.

Balgzand estimates of Macoma balthica total somatic production of $\sim 3$ or $\sim 4 \mathrm{~g}_{\text {AFDM m}}^{-2} \mathrm{yr}^{-1}$ for the entire population and $\sim 3 \mathrm{~g}$ AFDM m $\mathrm{m}^{-2} \mathrm{yr}^{-1}$ for the post-spat population are less than half the production of cockles Cerastoderma edule in the same area (Beukema \& Dekker 2006). The present estimate of $M$. balthica production would amount to between 5 and $10 \%$ of the estimated total benthic secondary production on Balgzand. Higher proportions have been reported only in the Bay of Fundy (Canada), where total primary and secondary production are relatively low relative to other intertidal-flat areas (Cranford et al. 1985).

\section{Local variability in production}

Estimates of mean Macoma balthica production at the 14 Balgzand sampling sites varied over almost an order of magnitude (Fig. 10a). Such marked variation appears not to be unusual. At 14 sampling stations in Torry Bay (lower Forth estuary, Scotland), Elliott \& McLusky (1985) observed similarly marked spatial variation in annual production in each of the $2 \mathrm{yr}$ of their study.

On Balgzand, local production estimates more or less reflected local variation in annual recruitment, with recruit densities tending to increase with increasing intertidal height (Fig. 10b). However, at extremely high levels (around or above MTL), low lifetime production per recruit (Fig. 10c,d) reduced productivity in the near-coastal area of Balgzand. Thus, although local production values showed a significant positive correlation with height, maximum values were nevertheless found at intermediate intertidal levels (Fig. 10a), where growth rates are maximized (Beukema et al. 1977, Beukema 1993). At the highest intertidal levels, i.e. at sampling stations close to the coast (Fig. $1 \mathrm{cf}$. Fig. 10a), growth rates appear to be depressed by short daily immersion times (Beukema et al. 1977), and annual mortality rates are relatively high, probably as a consequence of elevated bird predation and parasite loads (Beukema 1993). In Torry Bay (Scotland), Elliott \& McLusky (1985) observed similar relationships with height: at low intertidal levels, individuals of Macoma balthica were relatively long-living and reached a large size. At the lowest levels on Balgzand, low annual recruitment appears to particularly limit productivity (Fig. 10b), and may be a result of high shrimp predation on $M$. balthica spat in these areas (Beukema \& Dekker 2005).

\section{Variability in $P / \bar{B}$ ratios}

In populations in a steady state, long-term estimates of the ratio of somatic production divided by mean biomass $\bar{B}$ are equal to the instantaneous annual death rate $z$. This is true on a theoretical basis and is also observed in practice (Brey 1999). Because $\bar{B}$ values of Macoma balthica at the start and end of the long period of observation on Balgzand were similar, this population fulfills the steady-state criterion. Van der Meer et al. (2001b) found a mean $z$ of 0.50 for the adult (age $>10 \mathrm{mo}$ ) population of $M$. balthica on Balgzand. This value is indeed identical to the (weighted) mean estimate of the $P / \bar{B}$ ratio of adults $(0.5$; Table 1$)$. Spatial variation in mean $P / \bar{B}$ ratio estimates per site (shown in Fig. $7 \mathrm{~d}$ in relation to intertidal height) was also similar to observed spatial variation in $z$, ranging from $\sim 0.6$ at the highest Balgzand sampling sites to $\sim 0.3 \mathrm{yr}^{-1}$ at the lowest sites, as shown in Fig. 7 of Beukema (1993).

Year-to-year variability in age composition of a population is bound to result in temporal variability of observed annual $P / \bar{B}$ ratios, because these values are generally higher in young than in old animals (Fig. 4b). This was demonstrated for Macoma balthica in the Gironde Estuary by Bachelet (1982), in the Bay of Fundy by Cranford et al. (1985), and on Balgzand in the present study: see Fig. $4 \mathrm{~b}$ and note the opposite trends in Fig. 7a,b. The present study of the Balgzand population yielded substantially lower $P / \bar{B}$ ratio estimates in all individual age classes than did the Gironde study. This difference may be a consequence of omitting gamete production from Balgzand estimates, and of apparently higher weight losses outside the growing season at Balgzand than in the Gironde Estuary. In a Scottish estuary, Elliott \& McLusky (1985) recorded relatively low $P / \bar{B}$ ratio values and stated that such low values indicated that the population was under stress. The growth rates observed in their population were low when compared to other intertidal populations located in temperate climate zones.

As a result of variable age composition, annual estimates of $P / \bar{B}$ ratios (Fig. 7b) varied almost as much as those of annual production (Fig. 6b). Therefore, it is 
difficult to state a species-specific $P / \bar{B}$ ratio for $M a$ coma balthica. This problem will be common to all populations with a highly variable age composition, due to e.g. variation in success of annual recruitment (as often occurs in bivalves: Beukema et al. 2001a, Beukema \& Dekker 2005) or subsequent adult mortality. The mean value $\left(0.5 \mathrm{yr}^{-1}\right.$ for adults and $0.8 \mathrm{yr}^{-1}$ for the entire population) is well within the range of published values for other areas and close to their average (Table 1: 8-area mean is $\sim 1.0$ ). However, the high yearto-year variability shown in Fig. $7 \mathrm{~b}$ demonstrates the limited value of $P / \bar{B}$ ratio estimates that are based on $1 \mathrm{yr}$ of observation only. Moreover, published estimates of $P / \bar{B}$ ratios are generally not only based on very limited periods of observation but also on low numbers of sampling stations. All published $P / \bar{B}$ ratio estimates from multi-station studies reveal strong local variation (see notes of Table 1). For this reason, Bachelet (1982) rightly recommends prudent use of these ratio values when predicting $P$. Thus, both temporal (Fig. 7b) and spatial variability (Fig. 7 d) may lead to unclear results if published $P / \bar{B}$ ratio estimates are indiscriminately used in meta-analyses aimed at establishing general rules or global patterns (e.g. Cusson \& Bourget 2005b). Van der Meer et al. (2005) justifiably advised against the use of $P / \bar{B}$ ratios when estimating $P$ from easily obtainable values of $\bar{B}$.

\section{Factors underlying production variability}

By far most of the variability in lifetime production of Macoma balthica cohorts on Balgzand could be accounted for by initial numerical abundance: recruit numbers assessed at an age of either $\sim 3$ mo (Fig. 8a) or $\sim 10$ mo (Fig. 8b) explained $\sim 85 \%(\mathrm{r}=0.92)$ of subsequent lifetime somatic production. Van der Meer et al. (2001a) arrived at a similar conclusion for production by elimination in the same population from a study involving a slightly shorter period and by using data from March samples only (thus defining recruits as 10 mo olds). Their statistical analysis revealed that variables other than recruit density (with $r=0.89$ ), such as rates of growth and survival, added little to the explanation of variance of production. Moreover, their study revealed that recruit density only weakly affected subsequent growth and survival rates. In the present study, we included densities of recruits at a younger age and found that survival of recruits between August and March (i.e. from an age of $\sim 3$ to $\sim 10$ mo) strongly depended on initial density in August (Fig. 9c), which led to lower production per recruit in strong than in weak cohorts (Fig. 9a). However, this density dependence disappeared (Fig. 9b) when recruit density was assessed as late as March, i.e. at an age of $10 \mathrm{mo}$, as did Van der Meer et al. (2001a). To summarise: (1) if assessed after the first winter of life, initial cohort density can be used as a reasonably precise and linear predictor of subsequent production by a M. balthica cohort over its subsequent life; and (2) no strong density-dependent effects on production (e.g. by consistently lower growth rates in strong than in weak cohorts) are apparent after an age of $\sim 10 \mathrm{mo}$.

Annual production in long-lived species such as Macoma balthica is the sum of contributions from a number of cohorts (see Fig. 4a) of very different strengths (Fig. 8). Such additions tend to reduce variability: the coefficients of variation in long-term mean annual (multi-cohort) production values amounted to $59 \%$, compared with $91 \%$ in long-term mean individual cohort production values. As in cohort production, the most important single factor accounting for interannual variability in annual production was numerical density at the start of the growing season. However, in the case of annual production values, the contribution of density was restricted to $37 \%$ (compared with $85 \%$ in cohort production), and other factors (age composition, growth and loss) contributed significantly to the variability in net annual production. The difference can easily be explained: cohorts experience a number of years of differing growth and weight-loss conditions (thus, the mean conditions experienced would be roughly similar). In contrast, annual production reflects conditions in a particular year, and the growing conditions (such as food supply; Beukema \& Cadée 1991) and environmental factors that influence weight loss (such as winter temperature; Fig. 5) vary markedly among years. Food supply, in particular growingseason concentrations of diatoms, is positively and linearly related to individual weight gain in the annual growing season (see Fig. 5 of Beukema \& Cadée 1991), and is thus bound to influence annual production when estimated by the growth-summation method. The relationship between annual $P$, food supply and primary production will be elaborated in another (future) study, which will deal in particular with the dependence of total bivalve production on (long-term variation in) primary production.

In addition to temporal variability, local variability in Macoma balthica production was also strongly governed by numerical density (Fig. 10a,b). Thus, to explain the magnitude and variability in production of this species, the mechanisms behind variable numerical density should be studied as a priority. In particular, initial cohort density, i.e. recruitment success, is highly predictive for subsequent (cohort) production (Van der Meer et al. 2001a, see also Fig. 8).

Recruitment of Macoma balthica varies strongly from year to year (Bachelet 1986, Desprez et al. 1991, Beukema et al. 2001a, Strasser et al. 2003; see also 
Fig. 8). Like other bivalve species, $M$. balthica showed a declining trend in recruitment over recent decades on Balgzand (Beukema \& Dekker 2005) and in some other parts of the Wadden Sea (Strasser et al. 2003). Beginning in 1988 (ignoring the outlier of 1991), life-time cohort production values generally declined (Fig. 6a), whereas $P / \bar{B}$ ratio values generally increased (Fig. 7b). The year 1988 marks a significant regime shift in marine ecosystems (including zoobenthos communities) that was observed throughout the temperate zone of the Northern Hemisphere (Weijerman et al. 2005). The above changes in cohort production and $P / \bar{B}$ ratio values were governed by changes in annual recruitment success (see Figs. 8 \& $7 \mathrm{a}$, respectively). Bivalve recruitment variability in the Wadden Sea appears to be climate related, with better recruitment after cold rather than mild winters (Beukema et al. 1998, 2001a, Strasser et al. 2003). Especially after 1987, water temperatures were elevated relative to the long-term average in both winter and spring (see Fig. 1f of Beukema et al. 2001a and Fig. 3a of Philippart et al. 2003, respectively). Studies of the mechanisms behind the negative effect of winter-spring warming on $M$. balthica recruitment success point to an advancement of spawning in spring, leading to a mismatch of peak abundance of larvae with the day-length induced timing of the phytoplankton bloom, and concurrence of the arrival of post-larvae with the peak of abundance of their main predator, 0-group shrimp Crangon crangon (Philippart et al. 2003). Shrimps arrive earlier on tidal flats in spring after mild than cold winters (Beukema 1992). Further evidence for a decisive negative influence of shrimp abundance on the Balgzand $M$. balthica population in May (when the $M$. balthica post-larvae settle) was given by Beukema \& Dekker (2005), who observed an increase in shrimp abundance on tidal flats over recent decades and a significant negative correlation between shrimp abundance in May and subsequent $M$. balthica recruit numbers.

In conclusion, 2 groups of factors appear to govern the magnitude of annual production in Macoma balthica: climate and trophic factors. Climatic factors affect production, particularly via recruitment success (cold vs. mild winters, matching of peak abundance of larval stages with food and predator abundance) and thus numbers of producing animals. Furthermore, winter conditions affect net production via rates of weight loss after the growing season. Trophic factors (diatom concentrations in the growing season) affect production via individual growth rates, but seem to account for less of the between-year variability in production than does numerical density, which is mainly governed by climatic factors.
Acknowledgements. This study forms part of a long-term monitoring program on macrozoobenthos in the Wadden Sea executed by NIOZ and financially supported by the Dutch National Institute for Coastal and Marine Management (RWS/RIKZ). We are grateful to J. Drent and J. Van der Meer for discussing earlier versions of this paper and to 3 anonymous reviewers for their useful comments.

\section{LITERATURE CITED}

Bachelet G (1982) Quelques problèmes liés à l'estimation de la production secondaire. Cas des bivalves Macoma balthica et Scrobicularia plana. Oceanol Acta 5:421-431

Bachelet G (1986) Recruitment and year-to-year variability in a population of Macoma balthica (L.). Hydrobiologia 142: 233-248

Beukema JJ (1971) Productivity of Macoma balthica (L.) on a tidal flat area near Den Helder (Netherlands). Neth J Zool 21:213-214

Beukema JJ (1980) Calcimass and carbonate production by molluscs on the tidal flats in the Dutch Wadden Sea: I. The tellinid bivalve Macoma balthica. Neth J Sea Res 14: 323-338

Beukema JJ (1982) Calcimass and carbonate production by molluscs on the tidal flats in the Dutch Wadden Sea: II. The edible cockle Cerastoderma edule. Neth J Sea Res 15: 391-405

Beukema JJ (1992) Dynamics of juvenile shrimp Crangon crangon in a tidal-flat nursery of the Wadden Sea after mild and cold winters. Mar Ecol Prog Ser 83:157-165

Beukema JJ (1993) Successive changes in distribution patterns as an adaptive strategy in the bivalve Macoma balthica (L.) in the Wadden Sea. Helgol Meeresunters 47:287-304

Beukema JJ, Cadée GC (1991) Growth rates of the bivalve Macoma balthica in the Wadden Sea during a period of eutrophication: relationships with concentrations of pelagic diatoms and flagellates. Mar Ecol Prog Ser 68:249-256

Beukema JJ, Cadée GC (1996) Consequences of the sudden removal of nearly all mussels and cockles from the Dutch Wadden Sea. PSZN I: Mar Ecol 17: 279-289

Beukema JJ, Cadée GC (1997) Local differences in macrozoobenthic response to enhanced food supply caused by mild eutrophication in a Wadden Sea area: food is only locally a limiting factor. Limnol Oceanogr 42:1424-1435

Beukema JJ, De Bruin W (1977) Seasonal changes in dry weight and chemical composition of the soft parts of the tellinid bivalve Macoma balthica in the Dutch Wadden Sea. Neth J Sea Res 11:42-55

Beukema JJ, Dekker R (2003) Redistribution of spat-sized Macoma balthica in the Wadden Sea in cold and mild winters. Mar Ecol Prog Ser 265:117-122

Beukema JJ, Dekker R (2005) Decline of recruitment success in cockles and other bivalves in the Wadden Sea: possible role of climate change, predation on postlarvae and fisheries. Mar Ecol Prog Ser 287:149-167

Beukema JJ, Dekker R (2006) Annual cockle Cerastoderma edule production in the Wadden Sea usually fails to sustain both wintering birds and a commercial fishery. Mar Ecol Prog Ser 309:189-204

Beukema JJ, Desprez M (1986) Single and dual annual growing seasons in the tellinid bivalve Macoma balthica (L.). J Exp Mar Biol Ecol 102:35-45

Beukema JJ, De Vlas J (1989) Tidal-current transport of thread-drifting postlarval juveniles of the bivalve Macoma balthica from the Wadden Sea to the North Sea. Mar Ecol Prog Ser 52:193-200 
Beukema JJ, Cadée GC, Jansen JJM (1977) Variability of growth rate of Macoma balthica (L.) in the Wadden Sea in relation to availability of food. In: Keegan BF, Ceidigh PO, Boaden PJS (eds) Biology of benthic organisms. Pergamon Press, Oxford, p 69-77

Beukema JJ, Knol E, Cadée GC (1985) Effects of temperature on the length of the annual growing season in the tellinid bivalve Macoma balthica (L.) living on tidal flats in the Dutch Wadden Sea. J Exp Mar Biol Ecol 90:129-144

Beukema JJ, Essink K, Michaelis H, Zwarts L (1993) Year-toyear variability in the biomass of macrobenthic animals on tidal flats of the Wadden Sea: how predictable is this food source for birds? Neth J Sea Res 31:319-330

Beukema JJ, Honkoop PJC, Dekker R (1998) Recruitment in Macoma balthica after mild and cold winters and its possible control by egg production and shrimp predation. Hydrobiologia 375/376:23-34

Beukema JJ, Dekker R, Essink K, Michaelis H (2001a) Synchronized reproductive success of the main bivalve species in the Wadden Sea: causes and consequences. Mar Ecol Prog Ser 211:143-155

Beukema JJ, Drent J, Honkoop PJC (2001b) Maximizing lifetime egg production in a Wadden Sea population of the tellinid bivalve Macoma balthica: a trade-off between immediate and future reproductive outputs. Mar Ecol Prog Ser 209:119-129

Brey T (1999) Growth performance and mortality in aquatic macrobenthic invertebrates. Adv Mar Biol 35:153-223

Burke MV, Mann KH (1974) Productivity and production: biomass ratios of bivalve and gastropod populations in an eastern Canadian estuary. J Fish Res Board Can 31:167-177

Cadée GC (1986) Recurrent and changing seasonal patterns in phytoplankton of the westernmost inlet of the Dutch Wadden Sea from 1969 to 1985. Mar Biol 93:281-289

Cadée GC, Hegeman J (2002) Phytoplankton in the Marsdiep at the end of the 20th century: 30 years of monitoring biomass, primary production, and Phaeocystis blooms. J Sea Res 48:97-110

Chambers MR, Milne H (1975) The production of Macoma balthica (L.) in the Ythan estuary. Estuar Coast Mar Sci 3: 443-455

Chambers MR, Milne H (1979) Seasonal variation in the condition of some intertidal invertebrates of the Ythan estuary, Scotland. Estuar Coast Mar Sci 8:411-419

Cranford PJ, Peer DL, Gordon DC (1985) Population dynamics and production of Macoma balthica in Cumberland Basin and Shepody Bay, Bay of Fundy. Neth J Sea Res 19:135-146

Cusson M, Bourget E (2005a) Small-scale variations in mussel (Mytilus spp.) dynamics and local production. J Sea Res 53:255-268

Cusson M, Bourget E (2005b) Global patterns of macroinvertebrate production in marine benthic habitats. Mar Ecol Prog Ser 297:1-14

Dankers N, Zuidema DR (1995) The role of the mussel (Mytilus edulis L.) and mussel culture in the Dutch Wadden Sea. Estuaries 18:71-80

Dekker R, Beukema JJ (1993) Dynamics and growth of a bivalve, Abra tenuis, at the northern edge of its distribution. J Mar Biol Assoc UK 73:497-511

Dekker R, Beukema JJ (1999) Relations of summer and winter temperatures with dynamics and growth of two bivalves, Tellina tenuis and Abra tenuis, on the northern edge of their intertidal distribution. J Sea Res 42:207-220

Desprez M, Bachelet G, Beukema JJ, Ducrotoy JP and 5 others (1991) Dynamique des populations de Macoma balthica (L.) dans les estuaires du Nord-Ouest de l'Europe: première synthèse. In: Elliott $M$, Ducrotoy JP (eds) Estuaries and coasts: spatial and temporal intercomparisons. Olsen \& Olsen, Fredensborg, p 159-166

De Vlas J (1985) Secondary production by siphon regeneration in a tidal flat population of Macoma balthica. Neth J Sea Res 19:147-164

De Wilde PAWJ, Berghuis EM (1978) Laboratory experiments on the spawning of Macoma balthica; its implication for production research. In: McLusky DS, Berry AJ (eds) Physiology and behaviour of marine organisms. Pergamon Press, Oxford, p 375-384

Elliott M, McLusky DS (1985) Invertebrate production ecology in relation to estuarine quality management. In: Wilson JG, Halcrow W (eds) Estuarine management and quality assessment. Plenum Press, New York, p 85-103

Hiddink JG, Wolff WJ (2002) Changes in distribution and decrease in numbers during migration of the bivalve Macoma balthica. Mar Ecol Prog Ser 233:117-130

Honkoop PJC, Beukema JJ (1997) Loss of body mass in winter in three intertidal bivalve species: an experimental and observational study of the interacting effects between water temperature, feeding time and feeding behaviour. J Exp Mar Biol Ecol 212:277-297

Honkoop PJC, Van der Meer J, Beukema JJ, Kwast D (1999) Reproductive investment in the intertidal bivalve Macoma balthica. J Sea Res 41:203-212

Hummel H (1985a) Food intake of Macoma balthica (Mollusca) in relation to seasonal changes in its potential food on a tidal flat in the Dutch Wadden Sea. Neth J Sea Res 19:52-76

Hummel H (1985b) An energy budget for a Macoma balthica (Mollusca) population living on a tidal flat in the Dutch Wadden Sea. Neth J Sea Res 19:84-92

Lammens JJ (1967) Growth and reproduction in a tidal flat population of Macoma balthica (L.). Neth J Sea Res 3:315-382

Philippart CJM, Van Aken HM, Beukema JJ, Bos OG, Cadée GC, Dekker R (2003) Climate-related changes in recruitment of the bivalve Macoma balthica. Limnol Oceanogr 48:2171-2185

Strasser M, Dekker R, Essink K, Günther CP and 5 others (2003) How predictable is high bivalve recruitment in the Wadden Sea after a severe winter? J Sea Res 49:47-57

Van Aken HM (2003) One-hundred-and-forty years of daily observations in a tidal inlet (Marsdiep). ICES Mar Sci Symp 291:359-361

Van der Meer J, Beukema JJ, Dekker R (2001a) Long-term variability in secondary production of an intertidal bivalve population is primarily a matter of recruitment variability. J Anim Ecol 70: 159-169

Van der Meer J, Piersma T, Beukema JJ (2001b) Population dynamics of benthic species on tidal flats: the possible roles of shorebird predation. Ecol Stud 151:317-335

Van der Meer J, Heip CH, Herman PJM, Moens T, Van Oevelen D (2005) Measuring the flow of energy and matter in marine benthic animal populations. In: Eleftheriou $A$, McIntyre A (eds) Methods for the study of marine benthos. Blackwell Science, Oxford, p 326-407

Warwick RM, Price R (1975) Macrofauna production in an estuarine mud-flat. J Mar Biol Assoc UK 55:1-18

Weijerman M, Lindeboom H, Zuur AF (2005) Regime shifts in marine ecosystems of the North Sea and Wadden Sea. Mar Ecol Prog Ser 298:21-39

Wolff WJ, De Wolf L (1977) Biomass and production of zoobenthos in the Grevelingen estuary, the Netherlands. Estuar Coast Mar Sci 5:1-24

Zwarts L (1991) Seasonal variation in body weight of the bivalves Macoma balthica, Scrobicularia plana, Mya arenaria and Cerastoderma edule in the Dutch Wadden Sea. Neth J Sea Res 28:231-245 